\title{
Revisiting the Past: Material Negotiations between the Classic Maya and an Entombed Sweat Bath at Xultun, Guatemala
}

\author{
Mary E. Clarke $\odot$, Ashley E. Sharpe, Elizabeth M. Hannigan, \\ Megan E. Carden, Gabriella Velásquez Luna, Boris Beltrán \& \\ Heather Hurst
}

\begin{abstract}
Large material accumulations from single events found in the archaeological record are frequently defined as evidence of ritual. They are interpreted as generalized deposit categories that imply rather than infer human motivations. While useful in the initial collection of data, these categories can, over time, become interpretations in and of themselves. The emic motivations behind the formation process of 'ritual deposits' ought to be considered using a relational ontology as an approach to understanding how past populations interacted with non-human actors, such as structures and natural features on the landscape. The present study evaluates the assembly and possible function of a dense deposit of artifacts recovered from a Classic period sweat bath at Xultun, Guatemala. Analyses of the various artifact types and human remains in the deposit in relation to what is known of the social history of the sweat bath itself illustrate ontological relationships among offered materials as well as between the offering and the personified place in which it was recovered. We observe that with a better understanding of place, it is possible to evaluate the ritual logic in Classic Maya material negotiations.
\end{abstract}

\begin{abstract}
Maya ontology is one where few binary distinctions are drawn between the animate and inanimate. Caves, for example, are extensions of earth's hollow interior and places populated by gods and ancestral souls; however, caves are not strongly distinguished from constructed features, such as temple shrines or sweat baths (e.g. Prufer \& Kindon 2005; Pugh 2005; Vogt \& Stuart 2005). Both locations, as Brown and Emery $(2008,300)$ argue, 'mark important thresholds where human and non-human actors interact'. Offerings presented to these and other sacred locations are a means of ceremonial negotiation intended to produce tangible outcomes and real change in the world. The choice of proffered materials as well as the structure and timing of the offering are, therefore,
\end{abstract}

evidence of a ritual discourse. Breaking, smashing, burning, cutting and suffocating, among other destructive actions, effectively release the animate and vital matter from their intact form. Referred to as ch'ulel by the Tzotzil and $k^{\prime} u h$ by the Classic and Postclassic period Maya (c. AD 500-1500; Table 1), the vitalizing essence animating the world, as Houston $(2014,83)$ explains, can be 'segmented into beings with personality and predispositions [that adhere] to particular objects, places, effigies, even units of time'. This essence, however, cannot be created; it can only be transformed or transferred from an existing animate substance. Embedded in Classic Maya ritual practice was a material-mediated negotiation whereby sacrificed bodies, beings and objects

Cambridge Archaeological Journal 31:1, 67-94 (c) The Author(s), 2020. Published by Cambridge University Press on behalf of the McDonald Institute for Archaeological Research. This is an Open Access article, distributed under the terms of the Creative Commons Attribution licence (http:// creativecommons.org/licenses/by/4.0/), which permits unrestricted re-use, distribution, and reproduction in any medium, provided the original work is 
Table 1. Mesoamerican chronological periods for Xultun.

\begin{tabular}{|l|c|}
\hline Period & Years \\
\hline Middle Preclassic & $600-300$ BC \\
\hline Late Preclassic & 300 BC-AD 250 \\
\hline Early Classic & AD 250-550 \\
\hline Late Classic & AD 550-800 \\
\hline $\begin{array}{l}\text { Terminal Classic/ } \\
\text { Early Postclassic }\end{array}$ & AD 800-1050 \\
\hline
\end{tabular}

were the means of directing essence elsewhere. Material accumulations resulting from these negotiations offer an opportunity to evaluate emic perceptions of the specific needs and demands of a particular context, event, or animate place.

Within Maya archaeology, typological categories are used to define excavated ritual deposits. Small, intrusive deposits placed within constructed features, for example, are defined as caches, and also interpreted as offerings that fed or renewed an animate structure or place (e.g. Becker 1993; Chase \& Chase 1998; Coe 1959; 1965; Pendergast 1998). When deposits are larger in scale and found within foundations or later construction episodes, they are instead classified as a dedication or termination deposit. While a dedication ritual is interpreted as a way of imbuing a new construction with an animate soul (Brown \& Garber 2003, 92-3), termination rituals, on the other hand, are perceived as the means of releasing or killing a structure's soul (Freidel \& Schele 1989; Mock 1998; Stanton et al. 2008). These deposits are, however, found in similar locations, making them difficult to distinguish, save for occasional contextual clues. Similar issues are noted for the so-called problematical deposit (Iglesias Ponce de León 1988, 27). Frequently comprised of large volumes of midden-like materials recovered in final occupation levels, these deposits are common phenomena formed prior to site abandonment (Clayton et al. 2005; Houk 2000; Newman 2019) or as a result of post-abandonment pilgrimages (Navarro-Farr 2009). Materials range from shell ornaments, pottery sherds, partial or sometimes whole vessels, to animals and even occasionally human bones. Frequently burned, broken and scattered, these items were intentionally selected, often acted upon and then integrated into a larger offering with a specific aim. Extending from human beings to utilitarian goods, the animate world of the Classic Maya included an intricate network of relations that existed among diverse social actors.

In this article, we present an analysis of one particular deposit recovered at the Classic Maya site of Xultun, Guatemala (Fig. 1). In addition to analysing its structure and assembly, we include an evaluation of the relationships indicated by the contents and the context of the offering. This approach draws inspiration from the ontological turn in archaeology (e.g. Alberti \& Bray 2009; Alberti \& Marshall 2009; Henare et al. 2007), which incorporates indigenous ontologies into archaeological interpretive frameworks. As Harrison-Buck $(2015,65)$ explains, recent approaches depart from traditional definitions of animism as a set of beliefs (Tylor [1871] 1993) and instead consider 'a relational ontology centred on relationships between human and "other-than-human" agents' (e.g. Haber 2009; Harrison-Buck 2018; Harvey 2006). We consider a problematical deposit as evidence of a ritual discourse between human and non-human social actors, namely individuals from Xultun and a supernatural entity that embodied a particular sweat bath structure. Enveloping the façades of the Xultun sweat bath, Los Sapos, is an individual with limbs composed of iguana/toad conflations positioned so that the doorway is between their legs (Fig. 2). As one entered or exited this sweat bath, one also entered and exited this figure's body, blurring the boundaries between body, being and place (Clarke in press). Centuries after the personified sweat bath had been entombed, Xultun residents re-entered this context and added a large, complex offering that appears to be an intentional reference to the structure's identity. As there is a considerable history in the negotiations with personified sweat baths in Mesoamerica, we argue that it is possible to evaluate the relationship among offered materials as well as between multiple social actors engaged in this ritual discourse.

\section{Ritual work in an animate world}

The distinction between what is sacred and what is profane has shaped archaeological interpretations of past perceptions of the world. Rationalist, Western thought informs us that ceremonial or sacred locations are conscripted or contained, marked off and easily distinguished from the domestic or quotidian sphere of everyday life (Eliade 1959). Similar dichotomies have been suggested for ritual practice. Repetitive and layered with symbolic action, ritual practice, as Durkheim (1915) argues, necessarily differed from other performed actions, implying utilitarian practice, not to mention related objects and domestic places, were devoid of symbolic meaning (see Arnal \& McCutcheon 2013 and Brück 1999). Scholars engaging with indigenous perspectives of objects, places, and daily life, however, argue that 


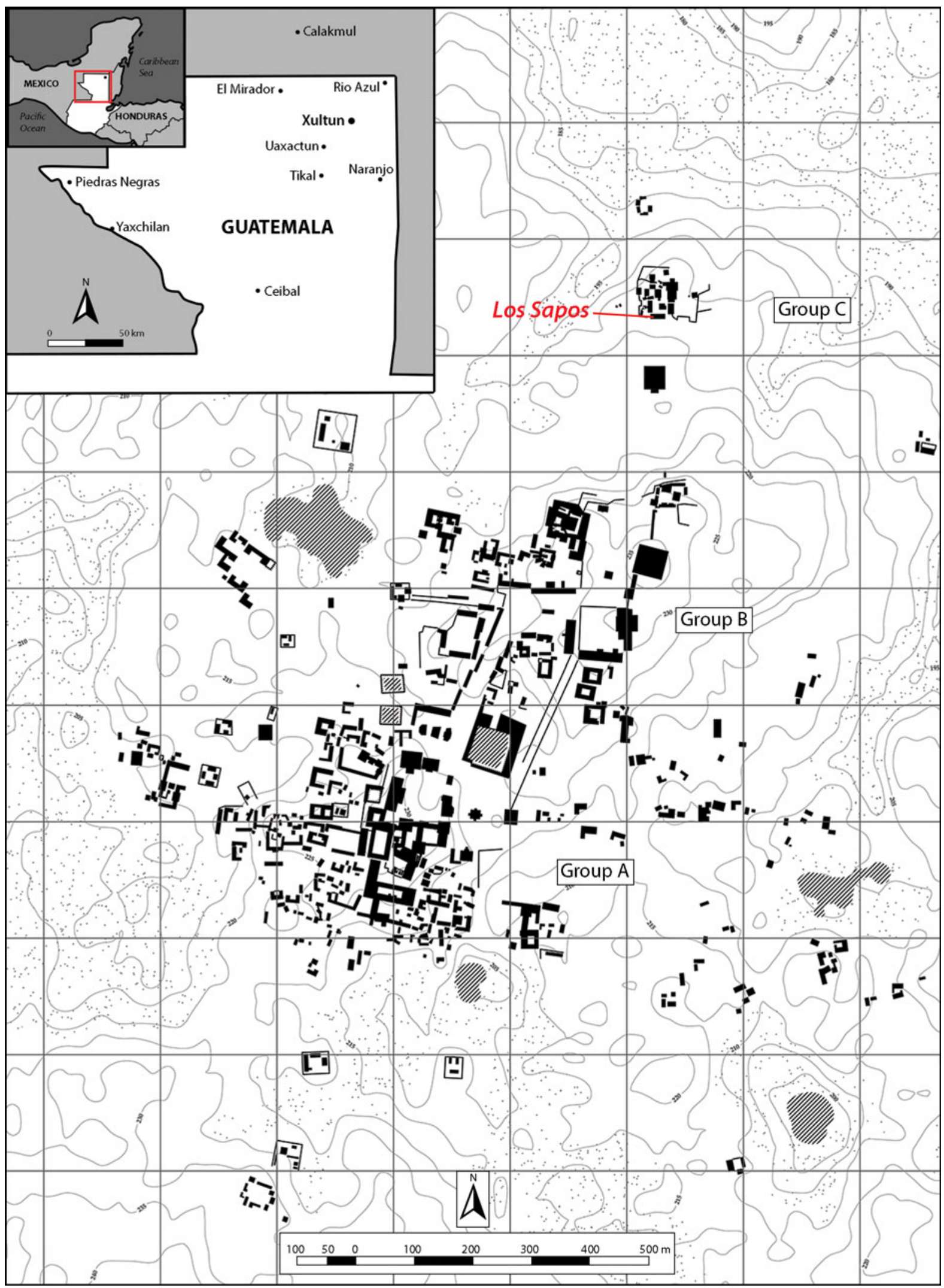

Figure 1. The location of Los Sapos at the site of Xultun with the site's global position illustrated within the inset map. (Map of Xultun produced by Carlos Chiriboga, 2016, elaborated by Mary Clarke, 2019.) 
Mary E. Clarke et al.
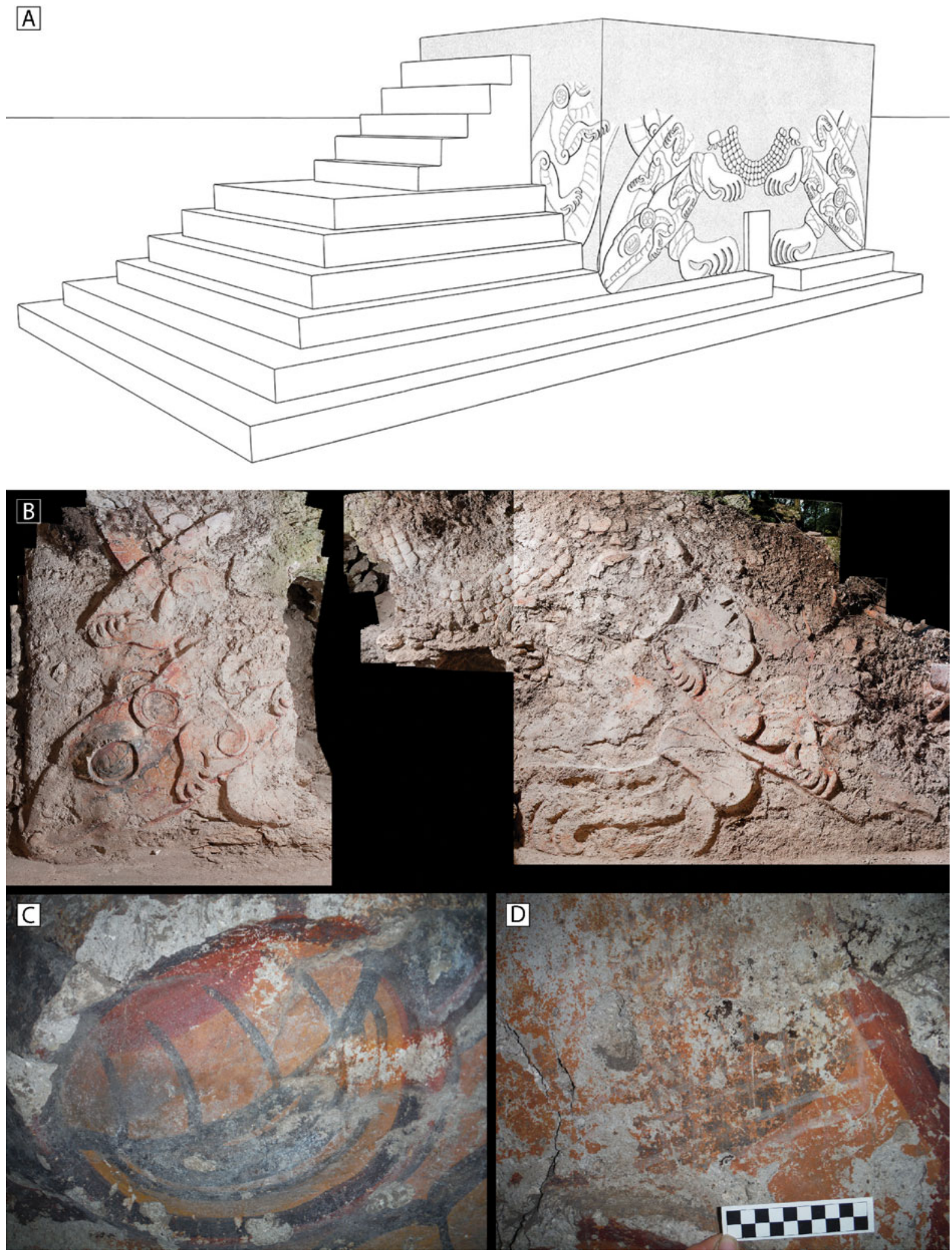

Figure 2. The sweat bath, Los Sapos: $(A)$ reconstruction of Los Sapos depicting both preserved façades and the adjoining staircase; (B) composite photograph of Los Sapos north façade (Courtesy of National Geographic Society, 2012); $(C, D)$ detailed photographs of the painted iconography. 
these heuristic tools inappropriately apply western epistemological notions. Specifically, they create divisions between symbolic and utilitarian modes of action where none exist (Alberti \& Marshall 2009; Bird-David 1999; Groleau 2009, 398; Hallowell 1960). This is particularly prevalent in animistic societies (Ingold 2006), such as those of Mesoamerica.

In indigenous Mesoamerican thought, ritual and religion are regarded as work in active terms where faith as well as practice are expressed through actions involving a perceived equivalence. The word meyah or 'work' in modern Yukatek Mayan is used, for example, to describe and equate actions such as a shaman's ritual performance, a farmer's act of burning a field and a woman's work of cleaning and sweeping a house (Hanks 1990, 334-5, 364). In Classic period Mayan texts, work in the royal court is likewise equated to that of manual labour, drawing parallels between 'burdens' of captive taking and those of cultivating agricultural fields (Houston et al. 2006, 225). In a similar manner, 'ceremony' is understood in quotidian terms. Among the modern Mixtec community of Nuyoo, Monaghan (2000, 32) observed that 'instead of officiating at a rite, practicing a ritual, or performing a ceremony, officiants are "feeding" or "straightening" or "sweeping".' These action-oriented expressions of the Mesoamerican belief system create, as McAnany $(2010,63)$ argues, a ritual practice in which 'ritual performance trumps abstract knowledge of theology, and religious pedagogy emphasizes practical epistemology over ideology.'

Akin to the understanding of faith and performed work, indigenous people of Mesoamerica have not, for the most part, drawn distinctions between the natural and supernatural as is done in Judeo-Christian beliefs. Rather, the supernatural is perceived to dwell within the natural (Monaghan 2000, 27), creating an animate landscape densely populated by non-human social actors. Features within and certain materials of the natural landscape present opportunities to converse with and otherwise engage supernaturals. This perception of the world is echoed in Mesoamerican cosmogony. In place of an ex nihilo mode of creation, creator deities made or shaped people from the already animate material in the world (e.g. Beliaev \& Davletshin 2014; Christenson 2003, 60; Guiteras Holmes 1961, 311; Tedlock 1996, 215). Although a unified version of these events does not exist, creation is generally understood as a consequence of multiple beginnings, trails, and demises triggered by the confrontations and misdeeds of different gods. In several modern myths from Maya communities, a sequence of three or four eras of creation have been recorded, where former peoples, having offended or slighted the gods, brought about their own demise (Christenson 2003, 66, 70-90; Tedlock 1996, 66-73). Embedded in these narratives is the notion that the current population is dependent on the continued satiation of the gods, an asymmetrical structure of 'original debt' (Earle 1986, 170) paid through ritual work.

The primary form of debt repayment and ritual work is providing gods with sustenance through prayer, offerings and sacrifice. Underlying these actions is the manner of converting a substance to an essence so that it may be readily consumed by gods (Graulich \& Olivier 2004, 125). By burning proffered materials, an offering becomes smoke and essence as well as sustenance. Depicted in swirling tendrils of vapour or scent, this essence wafts from smoking braziers as well as other sources, including aromatic flowers, freshly prepared food, and the mouths of individuals (Taube 2004). Other sources of divine nourishment are blood (Graulich 2005) and the bodies of humans and animals (Christenson 2003, 235-9; Tedlock 1996, 164-6). The origin of sacrifice as payment is traced by many Mesoamerican peoples to primaeval covenants with gods and the earth (Monaghan 1995). According to a K'iche narrative from Cubulco (Shaw 1971, 52-3), the ancestors hurt the earth when they first harvested it. As they were pulled out from the earth, weeds and trees cried out to god, asking for intervention. God reached a settlement between them, where the earth consented to endure the pains of cultivation and provide food and resources for humans so long as humans would feed the earth in return, both with their bodies at death and by satiating its hunger with chocolate, wine, liquor and beer throughout their lifetime.

Failure to perform the ritual work that upheld the covenants had tangible impacts on the lives of the living. The gods would react viciously; they might withhold food and much needed rains (Earle 1986, 163; Girard 1962, 153-4; López Garcia 2010, 79-121; Wisdom 1940, 439), allow sickness and prevent recovery (Guiteras Holmes 1961), and, as has happened in earlier epochs, instigate a revolt of objects, leaving people at the mercy of their own hostile household goods (Christenson 2003, 70-90; Gossen 2002, 171-3; Tedlock 1996, 66-73). Demands of exchange or offerings of payment were required in countless contexts. Clearing a forested area to make a milpa [corn field], for example, necessitated negotiation (Thompson 1963, 139), as did house construction. Among the Tzotzil of Zinacantan, Vogt $(1969,461)$ documented a ritual referred to as the 
hol chuch [good heart]. Halfway through the process of building a new house, a hole was dug into its unfinished floor and an offering of blood, smoke and liquor was fed to the earth in exchange for the materials used in its construction. 'If it is not fed', according to one Q'eqchi individual (Monaghan 2000, n. 15), 'the house will eat you. It wants meat', likening the house to a jaguar or ferocious beast. Interactions with animate materials and places called on the covenant, expecting exchange and demanding repayment (see McAnany 2010, 70-79). This is particularly true of the Mesoamerican sweat bath.

\section{Personifying the Mesoamerican sweat bath}

The traditional Mesoamerican sweat bath is a place for healing and hygiene, one frequently used by midwives in postpartum and perinatal care. However, these places are more than structures: they are relatives, ancestors, and supernatural beings. Chinchilla Mazariegos $(2017,105)$ notes that among the K'iche' of Santa Clara la Laguna, Guatemala, 'the sweat bath is Saint Anne, the mother of Mary, the mythical grandmother who helps healers treat disease and allows midwives to see unborn children inside their mother's womb and fix them if misplaced'. The equivalence of person and place is not unique to this community in western Guatemala. Among the modern Totonac of Puebla, Mexico, Ichon (1973, 120-22, 151, 297-8) documents the veneration of a group of mothers and grandmothers, the Natsi'itni, who own and preside over the entrance of the sweat bath. Both divine and dangerous, the Natsi'itni demand offerings from the Totonac in order to ensure the life and well-being of newborn infants (Ichon 1973, 333). Negotiations with these animate beings embodied in sweat baths is also found among the modern Otomi of Central Mexico. Galinier (1990, 152-3; 2004, 61-4) describes postpartum rituals where Otomi mothers must feed the sweat bath offerings of cornbread in order to appease its anger provoked by the presence of blood. The ritual work of negotiating with these structures was not exclusive to mothers and midwives. Among the Mam of Santiago Chimaltenango, Guatemala, Wagley (1949) explains that the sweat bath where one was first bathed remains an important place as it is also the location where an individual's afterbirth is buried. 'Each individual should therefore know where his afterbirth was buried', recounts Wagley $(1949,23)$, because 'one may be sick and the soothsayer's divinations may indicate that the treatment calls for prayers to be offered in front of the sweathouse in which one was "first bathed" and in which the "afterbirth" lives.' Sweat baths are known as mother or grandmother figures who are both beneficent and pernicious: as such they command attention and are seen as active members of Mesoamerican communities.

The process through which a grandmother figure became synonymous with the sweat bath is reflected in Mesoamerican mythology. Having translated and compared all known accounts of this myth, Chinchilla Mazariegos $(2017 ; 2018)$ notes that this goddess is both the grandmother and foe of twin heroes, individuals who, following their defeat of this goddess, go on to create the conditions for human life. The means of this deity's defeat is quite consistent in that she is almost always burned or killed inside the sweat bath, where some myths specifically locate her death within the structure's doorway. One example from the modern Chatino of Tepenixtlahuaca, Oaxaca, Mexico, includes the hero twins stating upon their victory: 'You will remain here, holy mother, and you will eat from what the children who will be born in the future give you. If they don't feed you, the children will die; everyone will come to you to have strength' (Bartolomé 1984, 11, trans. Chinchilla Mazariegos 2017, 110). Once killed or trapped in the sweat bath, the goddess becomes the structure, an understanding that is also evident in ethnohistoric documents from Mesoamerica. In the Nahua Codex Magliabechiano (Nuttall 1903, f. 77r), the face of the goddess Tlazoteotl is placed directly over the doorway of a sweat bath, making it quite clear that she presided over its entrance (Fig. 3) (Alcina Franch 2000, 215-312). During difficult deliveries documented among the Mexica of the Colonial period, midwives prescribed sweat bath treatments and called out to the goddess Toci ('our grandmother') or Temezcalteci ('grandmother of the sweat bath') for aid (Sahagún 1950-1982, bk 6, 142, 149, 151-60).

Although these mythological figures vary over the course of Mesoamerican history, they have similar personalities, which Chinchilla Mazariegos aptly summarizes:

[T] he grandmother is at once a primary creator goddess and an aggressive antagonist of the young heroes ... her grandchildren, by birth or adoption. Her personality ranges from a nourishing maternal figure to a pathetically lewd old hag and a rancorous child-eater. While not always explicitly identified with the earth, her behavior is consonant with the notion of the earth as a voracious mother who yields her fruits reluctantly and ultimately consumes her children. Overpowered by the heroes, the grandmother acquired an equally duplicitous role as the model midwife-the sweat bath-who 


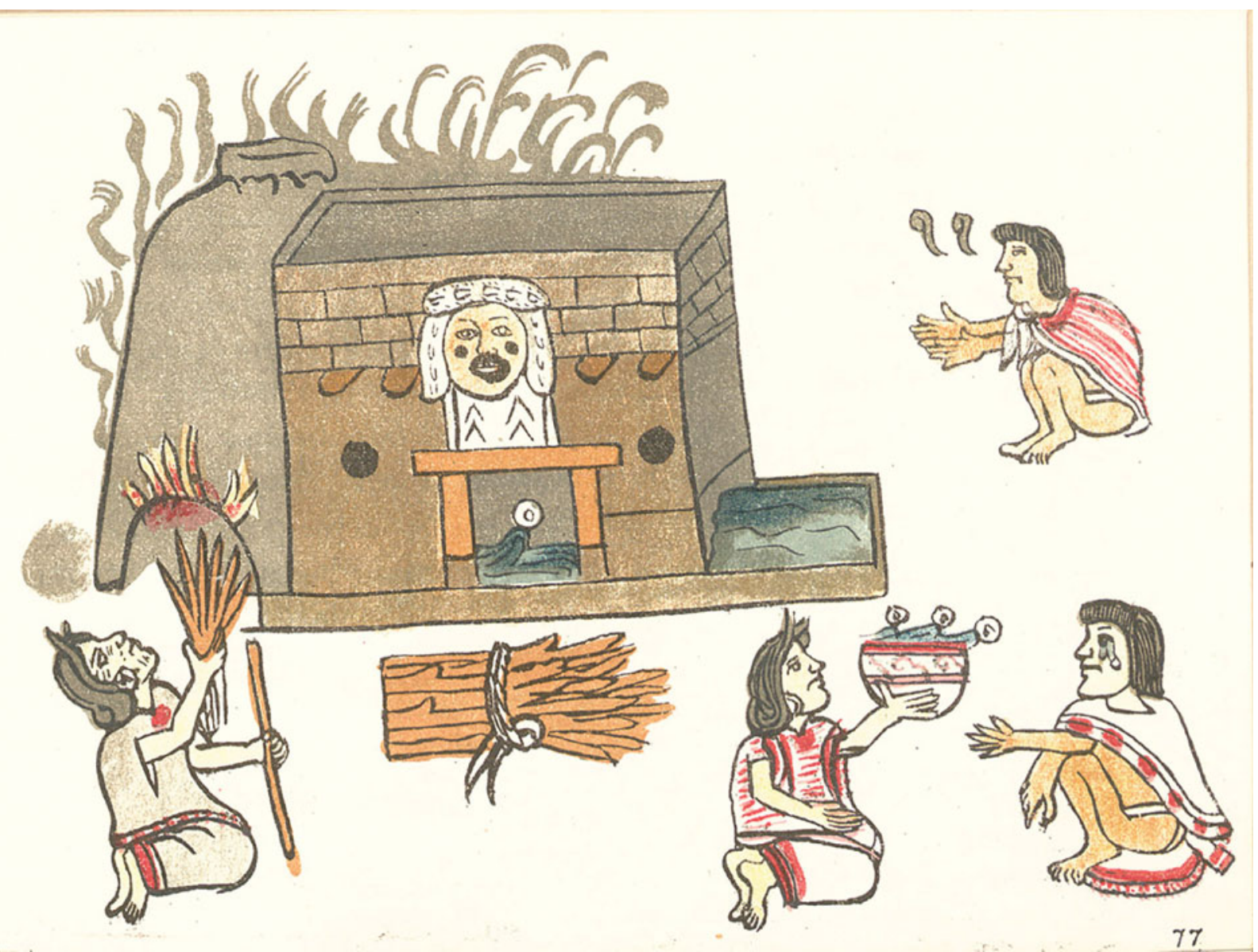

Figure 3. The Nahua Codex Magliabecchiano depicting a sweat bath with the goddess Tlazoteotl's face centred above the doorway.

delivers children on condition of being properly fed and appeased, but who may also retain them at will. (Chinchilla Mazariegos 2017, 128)

The Mesoamerican sweat bath is a place embodied by this duplicitous deity who holds sway over life and death. Failing to perform the ritual work that fed and cared for this being could have disastrous, if not fatal, consequences. Given the severity of this work, the low number of deposits recovered in and around sweat baths is surprising, particularly in Classic Maya contexts. With a total of eight excavated sweat baths, many of which included deposits with several thousand pottery sherds and large frequencies of obsidian, chert, bone, and ground stone materials (Child 2006; Mason 1935; Satterthwaite 1952), the site of Piedras Negras has perhaps the most robust evidence of these negotiations. Due to the inclusion of large amounts of ritually repurposed refuse, these offerings were interpreted as garbage dumps (Child 2006, 486, 539-40; see also Child \&
Golden 2008). By emphasizing relational ontologies over typological categories, we argue that a deposit recovered in front of a sweat bath, Los Sapos, which shares traits with the Piedras Negras sweat bath offerings, is instead a record of a ritual discourse between certain Xultun individuals and a personified sweat bath.

\section{Xultun and the sweat bath, Los Sapos}

Located on an elevated karst upland along the southern margin of the Bajo de Azucar in the Petén region of Guatemala, Xultun was an important centre of Lowland Maya civilization (Fig. 1). The first evidence of occupation at Xultun dates to the Middle and Late Preclassic period (c. 600 BC-AD 250; Table 1), with the site reaching its apogee in the Early Classic period (c. AD 250-550) (Urquizú \& Pérez 2019). During the subsequent years of the Late Classic period (c. AD 550-800), Xultun was a political ally as well as adversary to powerful polities such as Tikal 
(Houston 1992, 66-7), Los Alacranes (Garrison \& Stuart 2004, 853), Caracol (Garrison \& Stuart 2004, 853) and Motul de San José (Grube \& Nahm 1994). It was also actively producing monuments (AD 889) and maintaining its reservoirs (980-1080 cal. AD) well into the Terminal Classic period (c. AD 8001050). This large, urban centre was organized on a north-south axis, its architecture forming three general groups. The two southern groups, connected by parallel causeways, contain expansive plazas surrounded by numerous stelae, temple pyramids, ballcourts, palatial or administrative complexes and residential groups that extend into the periphery. To the north of these two groups and down a significant slope in the topography is the site's third group. Although this isolated area became a multi-functional residential complex in the Late to Terminal Classic periods (Wildt 2015), architecture dating to the Early Classic period indicates this area was an elaborate, ceremonial centre. Included in this early phase is the sweat bath, Los Sapos.

Within the corpus of Classic period Maya art and architecture, Los Sapos is an outlier. Its rectangular form, with a low, narrow entry in its north façade, is similar to most known sweat baths, as is its firebox located within the structure's steam chamber along its central axis. However, unlike most known sweat baths, Los Sapos emphasized the performed interaction with a central figure depicted on its exterior façades (Fig. 2). Poised in a squatting position, this figure wraps around the steam chamber where the doorway is between the figure's legs. Individuals exiting the structure, therefore, emerged as if (re) birthed from this being's body or contained place, perhaps equating the steam chamber with a hollow, womb-like interior. Use of the structure engaged other body parts as well. Defined by a staircase on the east façade, its back or spine could be scaled, leading from the length of this being's body to the top of the structure. The roof could have functioned as a platform or stage, particularly one that positioned performers on top of the figure's head or perhaps within its mouth. As the Classic Maya at Xultun used this sweat bath, therefore, they also confronted the embodied being.

The figure represented at Los Sapos is quite unique, in that there are but a few comparisons within the corpus of Maya art (Clarke in press). The most iconographically analogous deity from Early and Late Classic period imagery is a female goddess nicknamed the 'Yaxha Goddess' (Tokovinine 2013, 41). Depicted in her reptilian form on Yaxha Stelae 6, 10 and 13, she floats in an oceanic setting surrounded by anemones, while also functioning as a toponymic register that signifies a specific place (Fig. 4A). Labeled as te'nal yax chan $c h^{\prime} e^{\prime} n$ or 'tree corn [place] the blue-green sky cave', the location embodied by this deity, as Tokovinine (2013, 41-2) describes, was the blue-green centre of the world. The time-renewal events commemorated and portrayed on the Yaxha monuments, therefore, were performed in this sacred place that was located above or accessed through her mouth. This goddess is also referenced in Classic Mayan texts. Although her name remains undeciphered, Nondédéo and colleagues $(2018,337, n .3)$ have proposed a translation of 'ix.tzutz.sak'. Marc Zender (pers. comm., 2019) tentatively reads her name as 'the lady who finished (?made) squash seed(s)' or 'lady squash-seed-finisher (?maker)', alluding to an association with germination cycles, particularly their completion. This goddess is also depicted on what Houston (1996) describes as a symbolic sweat bath. Ornamenting the outer sanctuary of Palenque's Temple of the Cross, her head and upper limbs emerge from an oceanic environment (Fig. 4B). Akin to the Yaxha examples, her wide-open mouth acts as an entrance to a sacred place referred to in Palenque inscriptions as Matwil, a watery place of divine origin and ancestral emergence associated with the sea, conch shells and water birds (Stuart 2005, 79, 169). Similar conceptions of place are described throughout Mesoamerica, and it appears that during the Classic period, the Classic Maya anchored it within the body of a reptilian goddess tentatively named 'ix.tzutz.sak'. It is this figure and embodied place that we argue is represented at Los Sapos.

\section{The offering at Los Sapos}

Built in the Early Classic period, Los Sapos was in use as a sweat bath for approximately 250-300 years. The end of its use-life (562-651 cal. AD) was paired with a burial event (Fig. 5). First, an adult individual was interred within a cist tomb extending beyond the structure's doorway. With feet directly in the doorway, this individual was, according to Wildt (2015), positioned as if being birthed from the structure (Fig. 5B), although see Hannigan (2019) for a more in-depth analysis of this adult burial. Human interments are frequently recovered in liminal spaces, akin to the Los Sapos doorway (e.g. Ambrosino 2003; Balanzario 2011; Chase 1994; Haviland 2014, 406-7); however, human burials are rarely found in association with sweat baths (cf. Smith 1950, 96). In addition, many of the lower limb elements, particularly the patellar and femoral fragments, show clear evidence of burning (Figs. 5E \& 5F). 
Figure 4. Representations of the reptilian goddess from the Classic period: (A) Yaxha, Stela 13 (after a field sketch by Ian Graham); (B) the entablature of the symbolic sweat bath, the Temple of the Cross, Palenque, Mexico (after an illustration by Karl Taube).
A
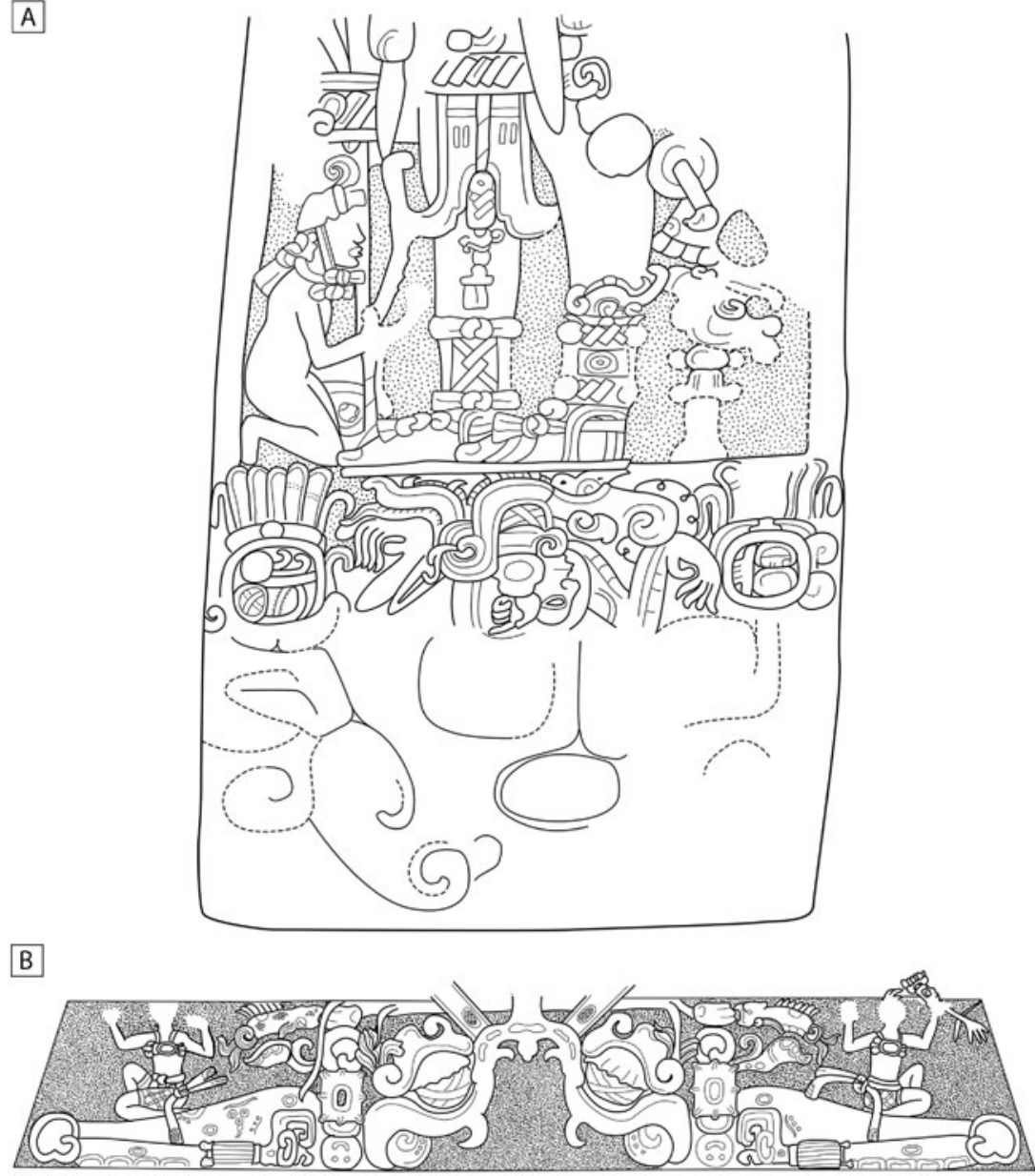

Second, the interior of both the cist tomb and structure were filled in using basket-loads of sediment (Fig. 5C) poured from above, after which Los Sapos was entombed within a subsequent construction phase.

Centuries later, the Classic Maya re-entered the cist tomb (Fig. 6). Radiocarbon dates place this second event within the Late to Terminal Classic period (776-971 cal. AD); however, the inclusion of Pabellon pottery, diagnostic of Xultun's Terminal Classic period (c. AD 850-1050), suggests the later end of this range. Approaching from the west, the Maya removed part of the cist tomb's masonry and the majority of the interred individual's remains. All elements above the distal epiphyses of the femora were removed, leaving behind only those positioned directly within the structure's doorframe. In their place, the Maya built a fire (Fig. 6F) and added a large ritual deposit, which included 1743 ceramic sherds, the remains of a juvenile human, numerous animal bones $(\mathrm{n}=521)$, complete and broken chipped, pecked and ground stone tools (excluding obsidian) and unworked chert flakes $(n=387)$, among other materials. In the following sections, we present analyses of ceramic materials and both human and faunal remains recovered within what appeared to be a problematical deposit. These analyses aim to identify the treatment and relational position of the assembled materials, and also the particulars of each artifact class, be it a species or iconographic representation.

\section{Pottery assemblage}

The deposit was predominantly of ceramic sherds $(n=1,743)$ and they were included in all stages of assembly. They have the potential to reflect the locations or multiple sequences of burning as well as the relational difference in artifact treatment, both prior to and during deposition. Ceramic materials were, therefore, reassembled and each of the related sherds were evaluated to determine continuities and differences in their treatment and position. Of the 1,743 sherds, a minimum vessel count of 124 was identified (only including rim sherds), with only 38 of those 

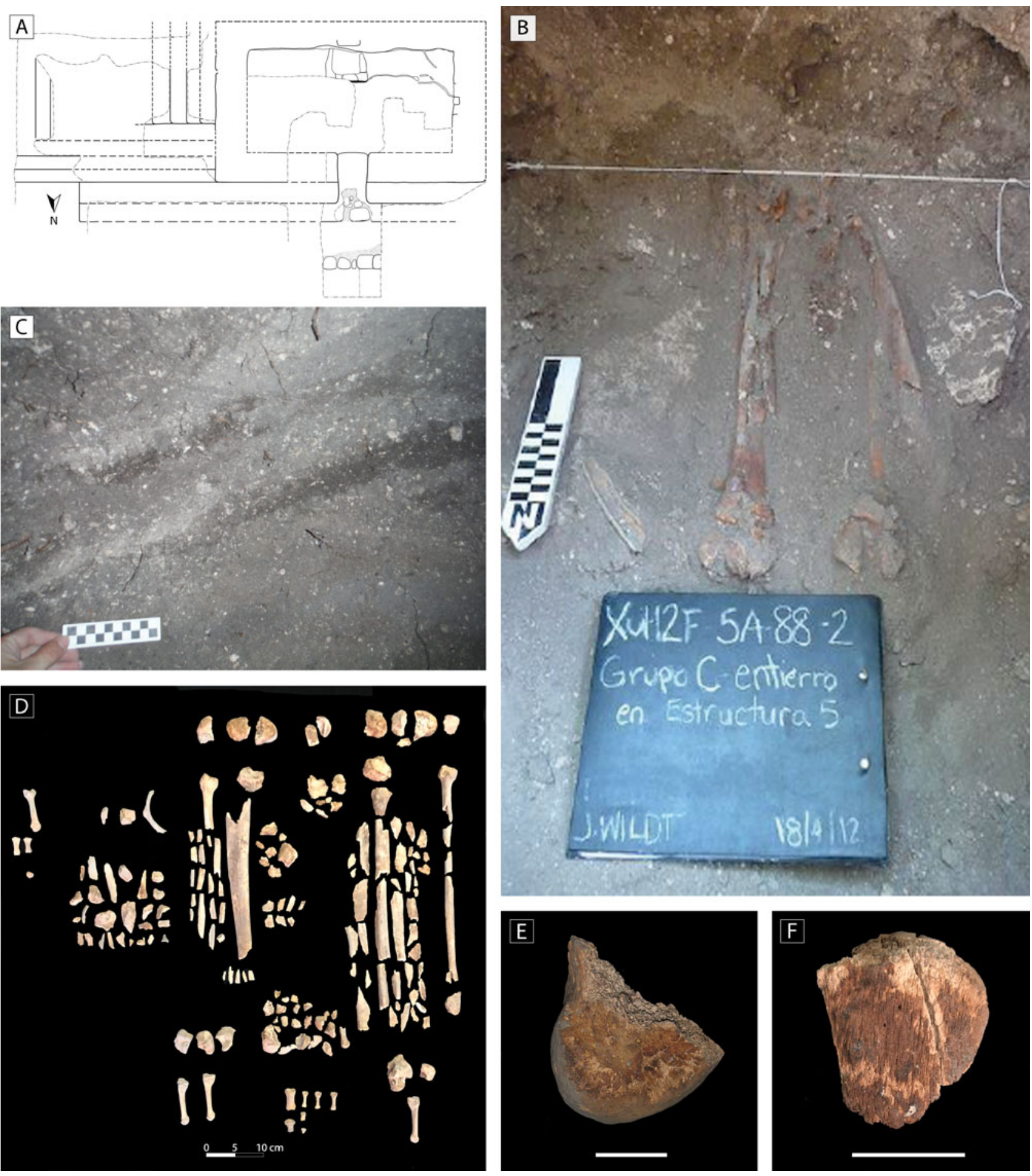

Figure 5. Early to Late Classic period burial located with the doorway of Los Sapos: (A) schematic of the sweat bath; (B) burned bones in situ with the fill context surrounding the remains (Photograph: Jennifer Wildt, 2012); (C) flow patterns visible in the structure's interior fill; (D) recovered skeletal elements (Photograph: David Del Cid, 2019); $(E, F)$ Evidence of burning on distal left femur.

vessels forming refits (Supplementary Table 1). However, there were also 16 distinct body sections that formed refits, although they did not include a related rim fragment ( $\mathrm{n}=83$ sherds). Body fragments from unslipped vessels were excluded from refit analyses $(n=440)$, as their similarities make them 

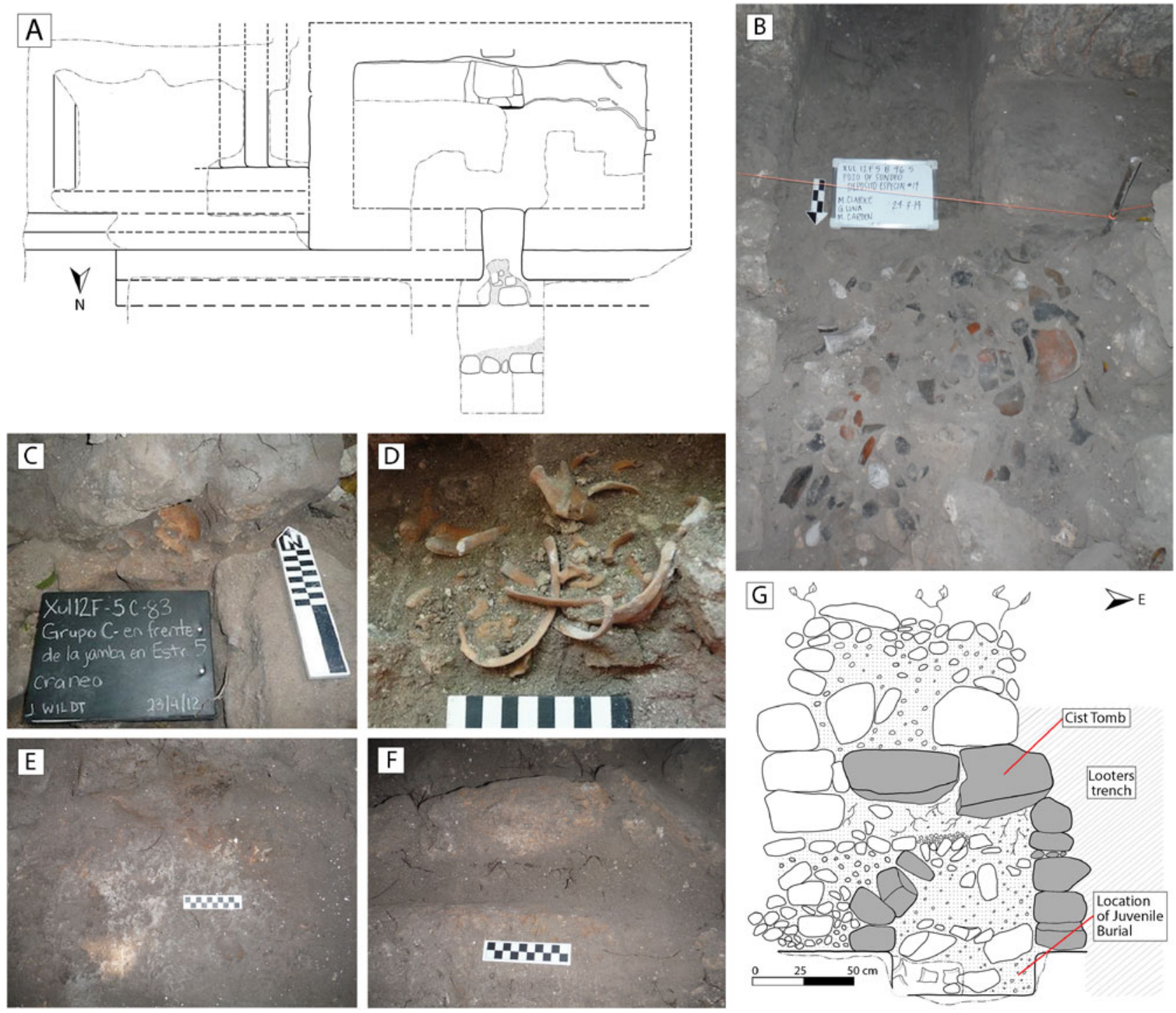

Figure 6. Details and contextual positioning of materials included in the Los Sapos deposit: (A) schematic of the sweat bath; (B) pottery assemblage; (C) cranium (Photograph: Jennifer Wildt, 2012); (D) postcranial skeleton (Photograph: Jennifer Wildt, 2012); (E) oxidation ring from burning event; $(F)$ burn patterning on the cist-tomb's masonry; $(G)$ north profile of the cist tomb.

difficult to differentiate without compositional analyses. Of the 38 vessels and 16 vessel bodies that formed refits, 33 (22 vessels and 11 bodies) suggest in situ breakage and 17 (11 vessels and 6 bodies) illustrate a wide distribution throughout levels and quadrants in the deposit area, probably created through scattering.

Vessels and bodies that were broken in situ show varying degrees of burning. Vessel \#6 was complete when deposited, but was excavated in seven fragments (Fig. 7A). The burn patterning along its exterior suggests that it was deposited whole, exposed to a single source of heat while still complete, and subsequently broken. Vessels and bodies that are more fragmented, however, suggest a different treatment and process of assembly. The four sherds that comprise Vessel \#16 (Fig. 7B), for example (38.5 per cent complete), show continuous burn patterning along all shared margins of sherds with direct refits. This pattern is also noted in certain refit body fragments (Figs. 7C \& 7D). The evidence of burning noted on the more fragmentary vessels indicates that burning was either part of the predepositional treatment or the observed burn patterns were artifacts of earlier use-lives. In the case of the latter, these fragmentary vessels would correspond 
Mary E. Clarke et al.

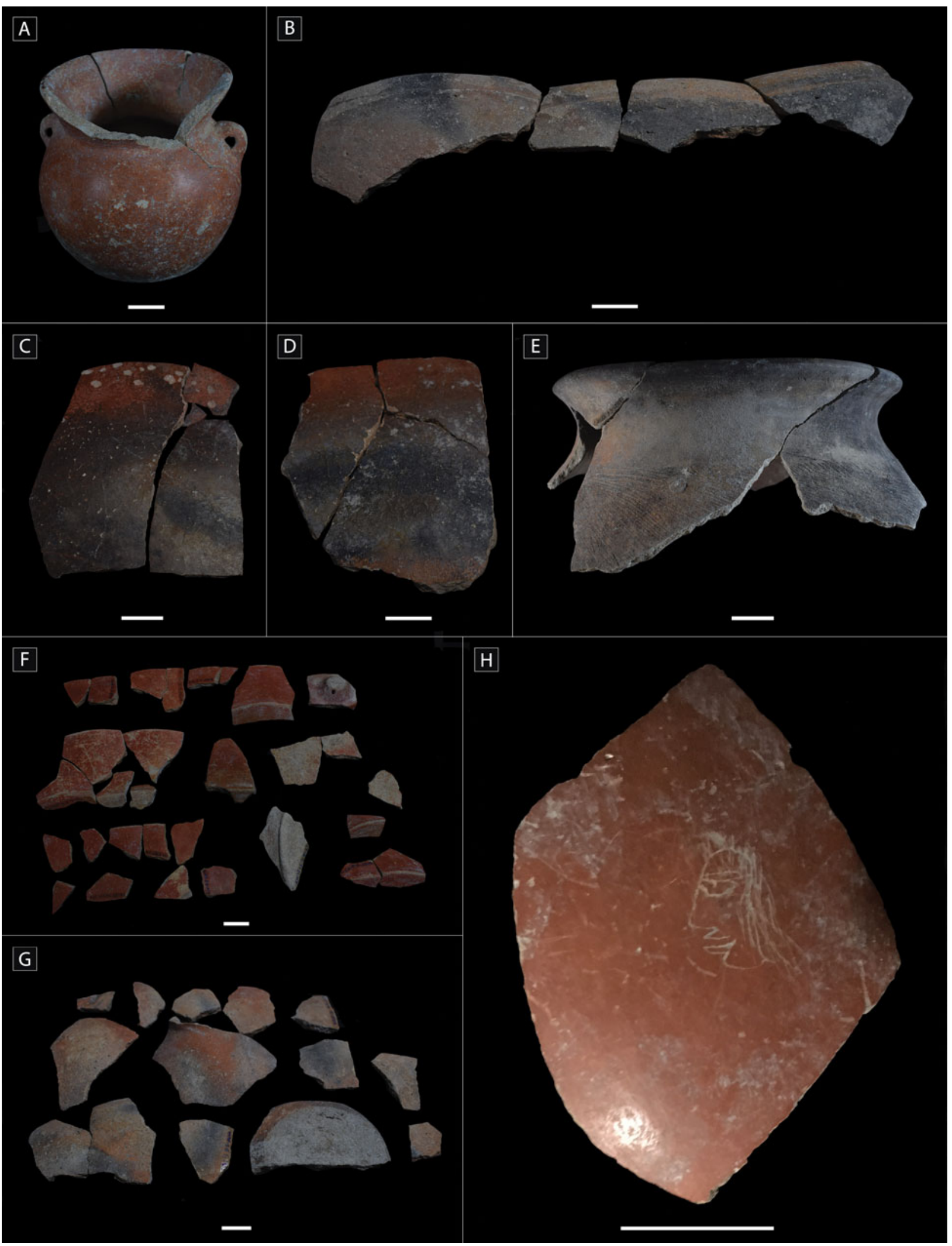

Figure 7. Selected vessel fragments mentioned in the text: $(A)$ vessel \#6; (B) vessel \#16; (C) body \#21; (D) body \#23; (E) vessel \#13; (F) vessel \#1; (G) body \#31; (H) graffiti sherd with head. All shown with $2 \mathrm{~cm}$ scales. (Photographs: David Del Cid, 2019.) 
to the ritual use of broken objects that, rather than being discarded, were set aside for future ritual work. When broken in situ, these potentially re-used vessel fragments were placed and stacked in the deposit without added burning, contrasting the treatment of complete vessels.

A total of 17 vessels were broken and then scattered throughout the deposit area. The associated sherds of Vessel \#13 (Fig. 7E), an example of a complete vessel, were recovered in multiple, non-joining quadrants within $0.30 \mathrm{~m}$ of one another. These sherds were direct refits that presented different levels of heat exposure along their shared margins. As indicated by the distribution and burning on the associated sherds, this complete vessel was broken as a pre-depositional treatment where its broken fragments were added at different times to different places and exposed to varying levels of heat likely after deposition. Heat exposure observed on other refit vessels scattered throughout the deposit varied considerably. Notably, 29 of the 30 fragments comprising Vessel \#1 show no signs of heat exposure despite their inclusion in contexts where burn patterning was noted on other vessel fragments. All 14 fragments of Body \#31 demonstrate some degree of heat exposure; however, these patterns are shared across their exterior, but certain sherds exhibit distinct burn patterns on their interiors. These examples indicate a similar pre-depositional treatment. Prior to being scattered, placed, stacked and, in some cases, burned, these complete and highly fragmented vessels were broken into smaller fragments and added at different points in the process of assembly as well as in different locations.

Two sherds from the deposit were also incised with graffiti. One rim fragment presents a crosshatching pattern, whereas another example, a body fragment, includes a human head (Fig. 7H). As they did not match other sherds within the recovered materials, either as direct or indirect refits, both sherds were identified as orphan sherds. One additional patterned modification was noted on Body \#21, discussed earlier, where certain refit sherds present patterned peck marks across the exterior (Fig. 7C).

Also recovered within the deposit were 10 ceramic figurine fragments. These recovered fragments were all distinct: refits between them were not possible. However, certain figurines were deliberately broken; meanwhile, others may have a thematic relationship with the structure. Three figurine fragments depict human heads, two of which show that their noses or mouths were deliberately broken (Figs. $8 \mathrm{~A}-\mathrm{C})$. As the cessation of breath, as opposed to the absence of a heartbeat, marked the end of life, these two figurines appear to have been sacrificed. A broad-brimmed hat worn by one of these sacrificed figurines appears to be similar to those worn by women vendors depicted in the Classic period Calakmul murals (Fig. 8A; Carrasco Vargas et al. 2009). This figure possibly represents a woman with a similar occupation. Another head fragment wears a headdress that appears to be a reptile with one eye open and one eye closed (Fig. 8C), suggesting a liminal placement, perhaps between night and day or death and life (Finamore \& Houston 2010, 252). Another figurine fragment depicts a slightly different reptile (Fig. 8D): specifically, it is portrayed open-mouthed with its tongue exposed. The larger figurine fragments depict sections of human bodies. A particularly complete example depicts a seated woman with one breast exposed and a child holding on to her side (Fig. 8E). The other notable fragment depicts the lower, front half of a human body with a missing element positioned between its legs (Fig. 8F). This broken element is curious, given the context, perhaps alluding to birth with something or someone, now missing, emerging from between the individual's legs. This fragment is also the only figurine to be extensively burned.

\section{Human remains}

The skeletal remains of a juvenile human were located just north of the sweat bath's doorway, both within a basin formed by the sweat bath's sunken drain and surrounded by an ashy matrix (Figs. 6C \& 6D). This individual was excavated during the 2012 field season where, due to time constraints, the individual was excavated vertically rather than horizontally from a trench profile (Wildt 2015). Original documentation of the juvenile remains suggests that the skull corresponded to a 12-year-old individual, while the postcranial remains were from a different individual of 1.5-2 years of age (Wildt 2015, 173). Several years later, a more thorough analysis of these remains was conducted, which focused on preservation and the burial context, as well as age-at-death, taphonomic alterations and trauma (Hannigan 2019).

The recovered skeletal elements are relatively complete and well preserved. The sample includes a number of small bones, such as phalanges and unfused sacral elements (Fig. 9). Despite the preservation of these small bones, there were many skeletal elements missing: the right humerus, radius and ulna, the left scapula, nine vertebrae, three ribs, three deciduous incisors and a number of hand and foot bones. The incomplete nature of the skeleton 
Mary E. Clarke et al.
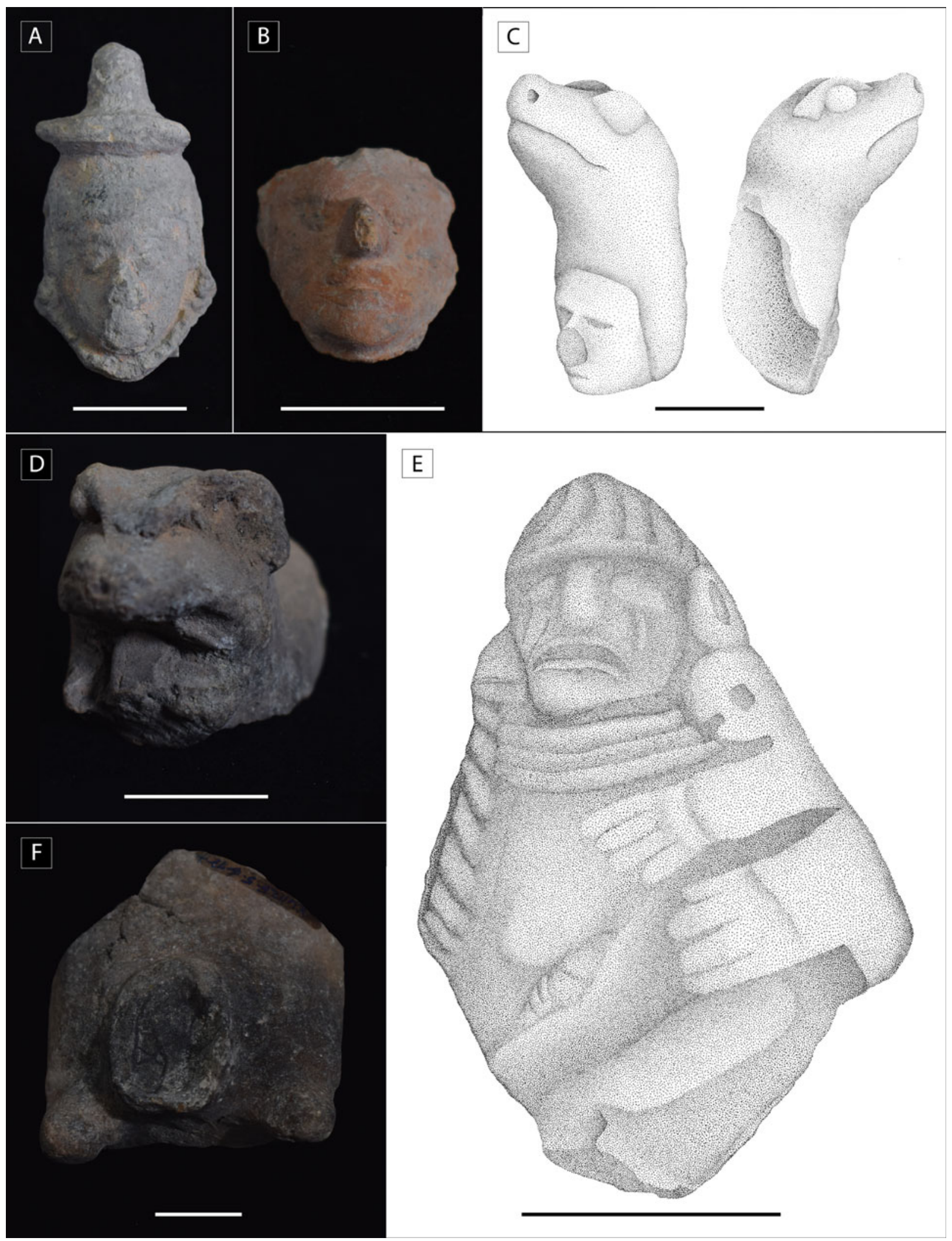

Figure 8. Figurine fragments mentioned in the text: $(A, B, C)$ representations of human heads; $(D)$ depicts a reptile; $(E)$ shows a woman and child; $(F)$ appears to be the lower half of a human with evidence of burning. All scales $2 \mathrm{~cm}$. (Photographs: David Del Cid, 2019.) 
Figure 9. Juvenile skeleton. Vertebrae are organized into groups of cervicall thoracic/lumbar but are not necessarily in the correct order; phalanges/carpals/ tarsals are arranged at the base of the image; unsided and unidentified fragments/elements are located in groups left of the juvenile. (Photograph: David Del Cid., 2019)

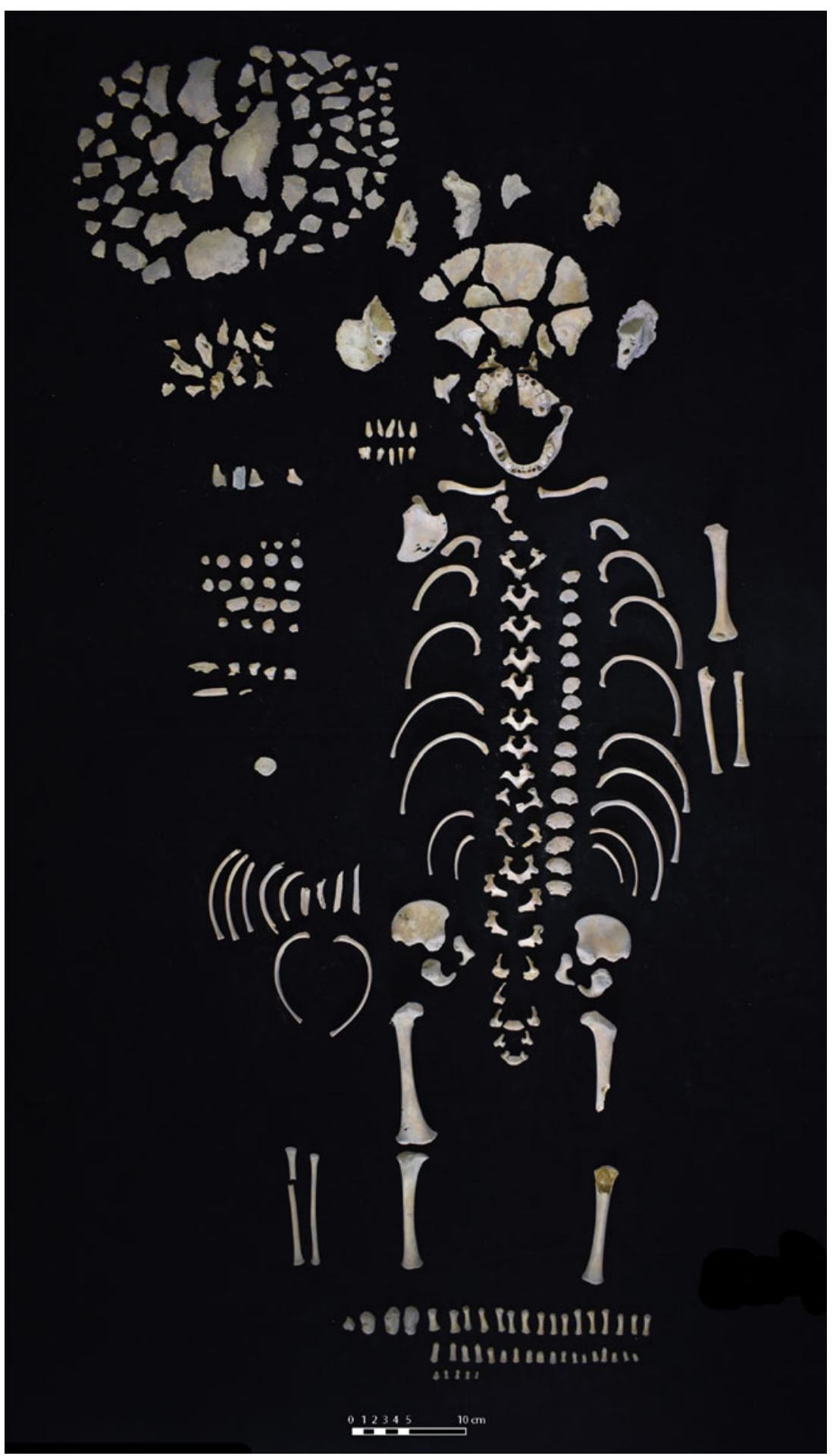

and its apparent disarticulation prevent a confident classification as a primary burial (Duday 2009, 25). Neither do the well-preserved skeletal elements indicate a secondary burial context following Jones' $(2018,220)$ definition: 'the collection and redeposition ... of skeletal elements in a location different from the original place of decomposition'. These discrepancies suggest that the juvenile interment may have been a primary burial that was altered through secondary treatments, defined by Moutafi and Voutsaki $(2016,784)$ as 'complete or partial disarticulation, selective or random bone removal and/or 
retention, limited or extensive relocation inside or outside the grave'. It is possible that some of the missing elements are the result of an incomplete recovery at the end of the 2012 excavation. It is just as possible that the missing juvenile elements were removed from the primary burial in antiquity, following decomposition. Such behaviour has precedents in Maya mortuary practices. Bone removal from primary interments is documented in several cases (e.g. Chase 1994; Novotny 2017; Scherer 2015, 99), although this practice is rarely noted in offertory contexts (cf. Ambrosino 2003; Domenici 2014; Tiesler 2007).

The initial age-at-death estimations suggested that two separate individuals were represented in the juvenile remains (Wildt 2015). The age-at-death analysis for the older juvenile was conducted using tooth eruption, whereas the age range for the younger juvenile was constructed using the ossification rate of vertebrae (Wildt 2015, 173). In our reevaluation, an age-at-death estimation was constructed based on an analysis of ossification rates of various skeletal elements following criteria established by Scheuer and Black (2000) and Schaefer and colleagues (2009). Both a closed metopic suture and the lack of an anterior bar on the ventro-lateral aspect of the articular pillar of the first cervical vertebra indicate that the age-at-death of the individual was $2-4$ years. This age-at-death estimate is also consistent for the entire skeleton including dentition, indicating that one, rather than two individuals are represented.

The inclusion of this juvenile individual within a problematical deposit appears to be uncommon. Similar deposits, defined as either a termination or problematical deposit, rarely include juvenile human individuals (cf. Iglesias Ponce de León 1988; Wrobel et al. 2013). Instead, the remains of human individuals of this age are more commonly included in deposits that are interpreted as sacrificial offerings (e.g. Kieffer 2015; Massey \& Steele 1997; Scherer 2018; Tiesler et al. 2002; 2012) or related to acts of ancestor veneration (e.g. Carroll 2015; Hotaling et al. 2017; Źrałka et al. 2017). However, observations pertaining to perimortem trauma noted during our analysis prevent the interpretation of sacrifice for this individual.

Cut marks or other perimortem trauma were not indicated on the individual's remains. While evidence of burning was present on one half of a vertebral neural arch, it was absent from all other studied remains. Because evidence of perimortem trauma is widely used to determine if juvenile remains were sacrificial offerings, the dearth of osteological evidence, in this case, presents a challenge. Burning as a method of juvenile sacrifice is commonly documented among the Classic Maya, where evidence of burning is pervasive and clearly exhibited on the skeletal remains (e.g. Chinchilla Mazariegos et al. 2015; Scherer 2018). However, not all methods of perimortem trauma leave clear evidence. Different methods of heart extraction, as Tiesler and Cucina $(2006,59)$ illustrate, do not present evidence of perimortem trauma. Children sacrificed as an offering to water/earth/fertility deities, according to Domenici $(2014,57)$, were killed by drowning or throat slitting, actions that often do not leave discernable marks. The absence of perimortem trauma exhibited on the juvenile's remains, therefore, does not dismiss the possibility that this individual was included in this deposit as an offering.

\section{Faunal assemblage}

Specimen counts for animals are reported as number of individual specimens (NISP) and minimum number of individuals (MNI). NISP was calculated conservatively, in that fragmented single elements from the same context were counted as one specimen, rather than individual fragments (for example, four pieces of a dog humerus were counted as one humerus, unless other characteristics such as size or side could clearly lead to the identification of two dog humeri). Thus, while NISP overestimates the number of individual animals in the deposit, it provides a close approximation of the number of individual bone elements recovered. In the cases of armadillo scutes and turtle shells, the number of scutes and carapace fragments are reported, along with a conservative estimate of the number of entire armadillo or turtle shells. MNI was quantified by estimating the minimum number of individual animals based on characteristics such as repeating elements of the same side, animal ages and chronological periods. MNI thus provides a better estimation of the true number of animals. In addition to species identifications and element counts, other characteristics were noted, including animal bone fusion and age, evidence of natural modifications such as root etching and rodent gnawing and evidence of burning, cut marks and other anthropogenic modifications.

Supplementary Table 2 shows the overall results of the fauna analysis, organized by construction phase and time period. The fauna are divided among four categories: the Early/Late Classic period fill from within the sweat bath chamber; the Early/ Late Classic period burial located in the doorway that was partially removed; the Late/Terminal 
Classic period problematical deposit in front of Los Sapos; and the Late/Terminal Classic period remains from deposits found on the west façade and further east along the north facade. Significantly, 79.4 per cent of all faunal remains were recovered from the problematical deposit. The remainder of this section will focus on this context.

The majority of identified animal bones were iguanas (Iguanidae, 23.4 per cent overall). Cane toads (Rhinella marina) and unidentified toads or frogs (Anura) were the second most common animals by NISP (17.1 per cent), although deer bones, particularly those of white-tailed deer (Odocoileus virginianus), were also common (11.6 per cent). Unidentified mammal long bone shaft fragments may have belonged to humans, deer, dogs, or any of the other medium-to-large mammals. Birds made up almost 20 per cent of the material, and those identified were mainly turkeys (Meleagris sp., 3.5 per cent) and water birds (2.4 per cent). Attempts were made to identify the iguanas, anurans, turkeys and fragmentary bird bones down to exact species, but without a direct comparative collection on hand this would be impossible in most cases. Based on the teeth shape of the iguanas, it would appear at least one is a green iguana (Iguana iguana). Future analyses of the material, preferably with comparative physical specimens of the different reptile, amphibian, and bird specimens, would allow for more precise identifications of individual taxa.

The analysis of the minimum number of individuals reveals a more accurate assessment of the number of animals (Supplementary Table 2). At least 30 individuals were recovered, 26 of which were vertebrates, along with four shells. The shells were found clustered together, and include two freshwater species (an apple snail and a freshwater mussel), and two marine gastropods (an olive shell and small conch); all except the mussel were intentionally modified with cut marks or drilled holes. Most vertebrate taxa were represented by one individual each, although in some cases there were multiple individuals of the same taxon, which may have been intentionally placed. For example, there were two partial gray fox (Urocyon cinereoargenteus) crania (Fig. 10), although no other gray fox skeletal elements were recovered, suggesting that the crania were placed alone in the deposit. Scattered throughout were three adult white-tailed deer skeletons, along with a fourth juvenile deer that may have been the same species, but due to its young age (all elements were unfused), it was impossible to discern whether it was a juvenile white-tailed deer or a brocket deer (Mazama sp.). At least three water birds that resembled rails (cf. Rallidae) were also recovered, and appear to be older juvenile or subadult individuals based on their lack of fully developed leg bones.

There were also four iguanas, including two large and two small individuals, based on their size and repeating same-sided elements (Fig. 11). The iguanas appear to have been deposited originally as complete skeletons, since many cranial and postcranial elements from the four individuals were recovered; likely the missing fragments remained in the parts of the deposit that were not excavated, or deteriorated post-deposition. Finally, two large adult cane toads and at least one (although possibly two based on differences in size) small unidentified frogs or toads were also found (Fig. 12). It is unlikely that the iguanas and toads were chance intrusions in the deposit, in part because the deposit was sealed, because these animals cannot burrow several metres into soil, because there was a lack of the more common intrusive animals usually found in Maya deposits (i.e. rodents) and because, as will be mentioned, some of the iguana bones were burned.

As Table 2 shows, many animals added to the deposit were juveniles or subadults. As was mentioned, the partial skeleton of a very young deer was included. The unfused radius of a dog was also recovered, indicating it was less than a year old. Concerning the possible rail birds, two tibiotarsi and two tarsometatarsi had unformed/fused ends, suggesting these belonged to a juvenile bird (Fig. 13). In the case of the iguanas, there were at least two larger and two smaller, and therefore younger, individuals.

For the most part, evidence for burning was limited (Table 3). Only 2.3 per cent of specimens in the deposit were burned. Burning does not appear to be concentrated in a particular area. Interestingly, two of the iguana bones were burned black, including a partial ulna and the spinous process and arch of a broken vertebra (found near but not adjacent to each other). This indicates that, although the entire termination deposit consisted of an ashy matrix, most of the bones were not exposed to flame. Except for the clearly burnt bones, most do not exhibit the signature browning inherent in bones placed near a heat source. It is likely the iguanas were deposited as articulated skeletons and not defleshed, since cranial and postcranial elements are represented, and vertebrae tend to be found concentrated in certain lots. The burnt elements appear to be the result of exposure to a short-lived flame.

There is slightly more evidence of cutting, incising and polishing of bones, as well as most of the 


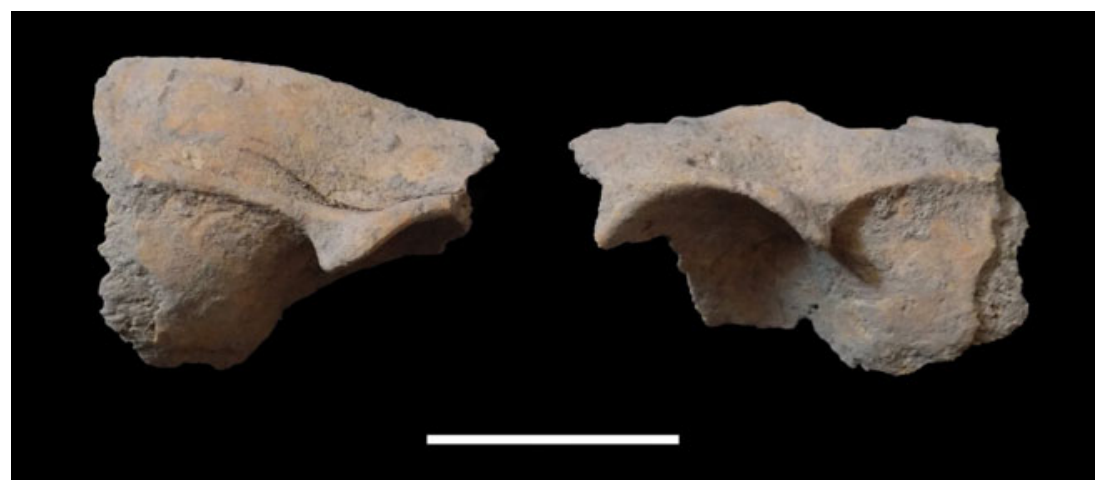

Figure 10. Two partial parietal/frontal bones from a gray fox (Urocyon cinereoargenteus) cranium. Scale 2 $\mathrm{cm}$.

shells (5 per cent of specimens) (Fig. 14). These artifacts appear to have been crafted for ornamentation, hinting at their life before final interment with the deposit. Three of the dog bones were cut, two in the form of bone tubes. At least five mammal bone pins were recovered, two of which appeared to be either a broken fragment or an awl in the process of production, possibly formed from a deer antler. Three large bone rings carved into possible beads were recovered as well, at least one carved from what appears to be the humerus of a white-tailed deer. Only three bones were found with potential butchery-style cut and scrape marks, although since these were fragments, we cannot rule out that these, too, may have been the results of crafting activities.

\section{Evaluating relational ontologies at Los Sapos}

Originally classified as a problematical deposit, comprehensive analysis of the items included in the Los Sapos offering presents an opportunity to evaluate the means to which materials mediated a ritual discourse. This offering reflects a series of actions that aimed at converting offerings into essence in the hopes of generating real change in the present. In some cases, burning was the means of conversion. Certain items were carefully placed into the deposit as whole objects as the fire within the vacated cist tomb was blazing, whereas others were added as the fire began to cool and burn unevenly. The latter appears to be the case with the juvenile human individual as well as certain fauna and ceramic vessels, each reflecting different levels of heat exposure. Incomplete materials showing evidence of extensive use-lives, such as ceramic materials and worked bone, particularly the broken pins, were also included in the offering. Only select items within this ritually repurposed refuse were acted upon. While some were burned, most were broken or smashed and then scattered or intentionally stacked within the offering. Although certain contents were intentionally placed, we did not identify a pattern in the assembly that indicates either the position of or the spatial relationships between placed items were significant. That said, there do appear to be thematic relationships among the offered items.

The artifacts included in the deposit reflect a certain logic in that they appear to have been chosen at least in part because they had a direct association with the structure's identity. This is perhaps most evident in the juvenile human remains, the juvenile deer and bird bones and the figurine of an aged mother, all of which relate to notions of birth and parturition. These related offerings can be attributed to the sweat bath's function as a place of birth and purification, but also the primordial place and generative role attributed to the goddess 'ix.tzutz.sak'. There is also a clear bias towards aquatic animals. The four clustered shells, rail birds, iguanas, and cane toads recall the watery iconography that surround representations of this deity and the characterization of Matwil, the primordial place she is said to embody at Palenque. It cannot be determined for certain, but it appears that the number of shells, toads and iguanas was significant, and may have been four (in the case of the toads, it was difficult to discern whether there were three or four). Iguanas were known to be consumed during feasts, such as described by Landa in the Yucatan Postclassic Muan festival (Tozzer 1941, 164); a mix of multiple iguanas and toads, however, seems to be unique to this deposit, especially given that they were also represented as figurine fragments. It would appear that they were intended to mimic the structure's external iconography; however, based on the ceramic materials from fill surrounding the structure, the façades were probably hidden from view at the time of re-entry. The individuals who made the offering were not those that used the sweat bath, since 


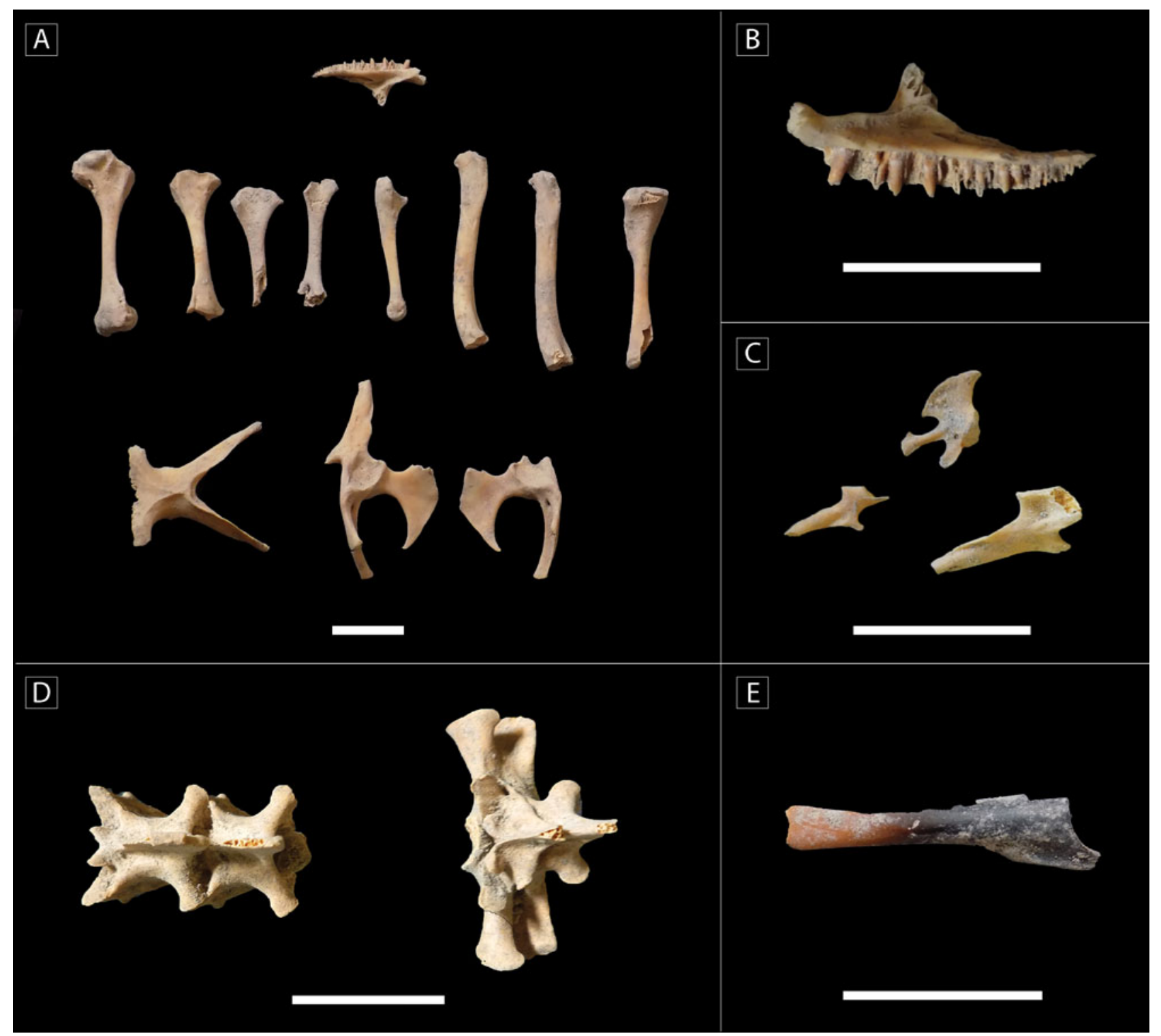

Figure 11. Some of the skeletal elements belonging to the four iguanas (Iguanidae): (A) mixed skeletal elements (humeri, femurs, tibia, ulna, maxilla, sternum, and pelvis); (B) maxilla, close-up; (C) unfused pelvic bones belonging to juvenile iguanas; (D) large thoracic and lumbar vertebrae of an older individual (note these two sets of vertebrae are fused); (E) a burned ulna. All scales $2 \mathrm{~cm}$.

Los Sapos had been entombed for approximately 200-300 years by the time the final offering was put in place. Therefore, the inclusion of thematically related materials suggests that this figure's identity may have been preserved in part of a social memory. Indeed, personified sweat baths are found throughout Mesoamerican history, many of which continue to hold important roles as social actors within contemporary Maya communities. For most of Mesoamerican history, indigenous perspectives of the personified sweat bath have had much in common. In order to secure the conditions for human life, the twin heroes killed the ferocious and cruel grandmother goddess after which she became the sweat bath. These structures are mother and grandmother figures who may offer help or elect to destroy or consume a living population.

The connections between modern or historic conceptions of sweat baths and those of the Classic period are admittedly tenuous, although they are not entirely absent. For example, old goddesses are represented as midwives aiding in scenes of 

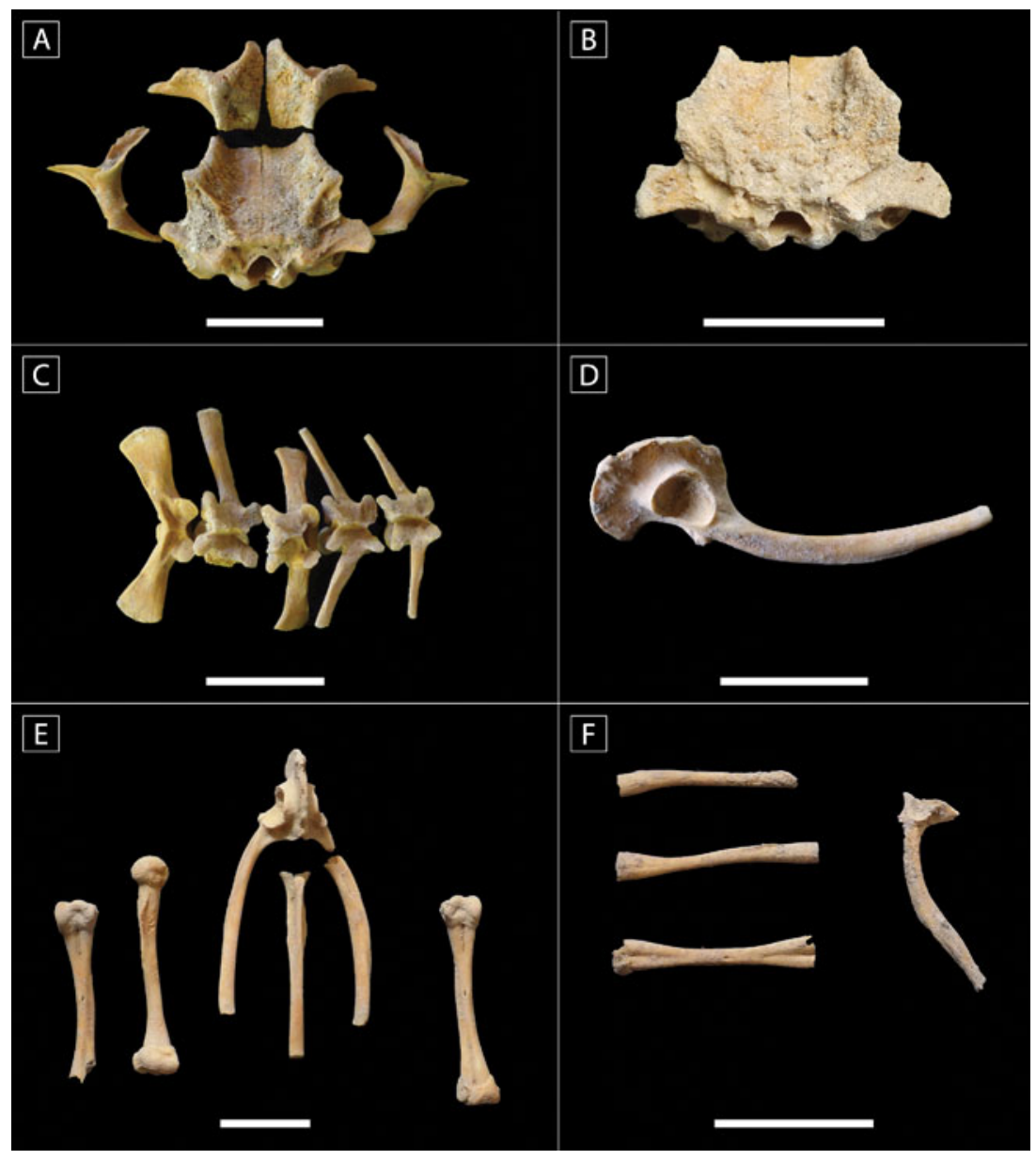

Figure 12. The assortment of toad bones placed in the offering:

(A) cranium of one of the large cane toads (Rhinella marina); (B) partial cranium of the second large cane toad in the offering; $(C)$ vertebrae of large cane toads (mixed, from both toads); (D) innominate (pelvis) of one large toad; (E) assorted elements from a large cane toad (tibiotarsi, humerus, pelvis, urostyle); ( $F$ ) assorted elements from a small toad or frog (humeri, tibiotarsus, pelvis innominate). All scales $2 \mathrm{~cm}$.

supernatural birth (Taube 1994). What remains unclear, however, is if these old goddesses were understood as the mythological figures who, as a result of being defeated, became the sweat bath. The limited iconographic sample from Classic period Maya sweat baths instead show that the reptilian

Table 2. Subadult and juvenile individuals recovered from different contexts, according to MNI estimates. Subadults are near-adult size with unfused or fusing appendages. Juveniles have unfused appendages and are considerably smaller than adult size. No young animals were recovered from the EC/LC construction fill context.

\begin{tabular}{|l|l|c|c|c|c|c|c|}
\hline & & \multicolumn{2}{|c|}{$\begin{array}{c}\text { EC/LC burial in } \\
\text { doorway }\end{array}$} & \multicolumn{2}{c|}{$\begin{array}{c}\text { LC/TC large deposit } \\
\text { within cist construction }\end{array}$} & $\begin{array}{c}\text { LC/TC deposit } \\
\text { outside cist } \\
\text { construction }\end{array}$ \\
\hline Species & Common name & Subadult & Juvenile & Subadult & Juvenile & Subadult & Juvenile \\
\hline Canis lupus familiaris & domestic dog & 1 & 0 & 1 & 0 & 1 & 0 \\
\hline Odocoileus virginianus & white-tailed deer & 0 & 0 & 1 & 0 & 0 & 0 \\
\hline Cervidae & deer, white-tailed or brocket & 0 & 0 & 0 & 1 & 0 & 0 \\
\hline cf. Rallidae & rail-type bird or small water bird & 0 & 0 & 1 (or juvenile) & 0 & 0 & 0 \\
\hline $\begin{array}{l}\text { Aves, } \\
\text { medium/small }\end{array}$ & bird, size of small raptor & 0 & 0 & 0 & 1 & 0 & 0 \\
\hline Trachemys venusta & Mesoamerican slider & 0 & 0 & 1 (small) & 0 & 0 & 0 \\
\hline Iguanidae & iguana & 0 & 0 & 0 & 2 & 0 & 0 \\
\hline Total & & 1 & 0 & 4 & 4 & 1 & 0 \\
\hline
\end{tabular}


Figure 13. Examples of juvenile animals in the deposit: (A) leg elements of a young stilt-legged bird (femur, tibiotarsi, tarsometatarsus; note proximal ends of bones are not yet fully developed); (B) unfused pelvic bone of a very young deer; $(C)$ unfused humerus missing proximal head of a subadult deer, an older individual than B. All scales $2 \mathrm{~cm}$.
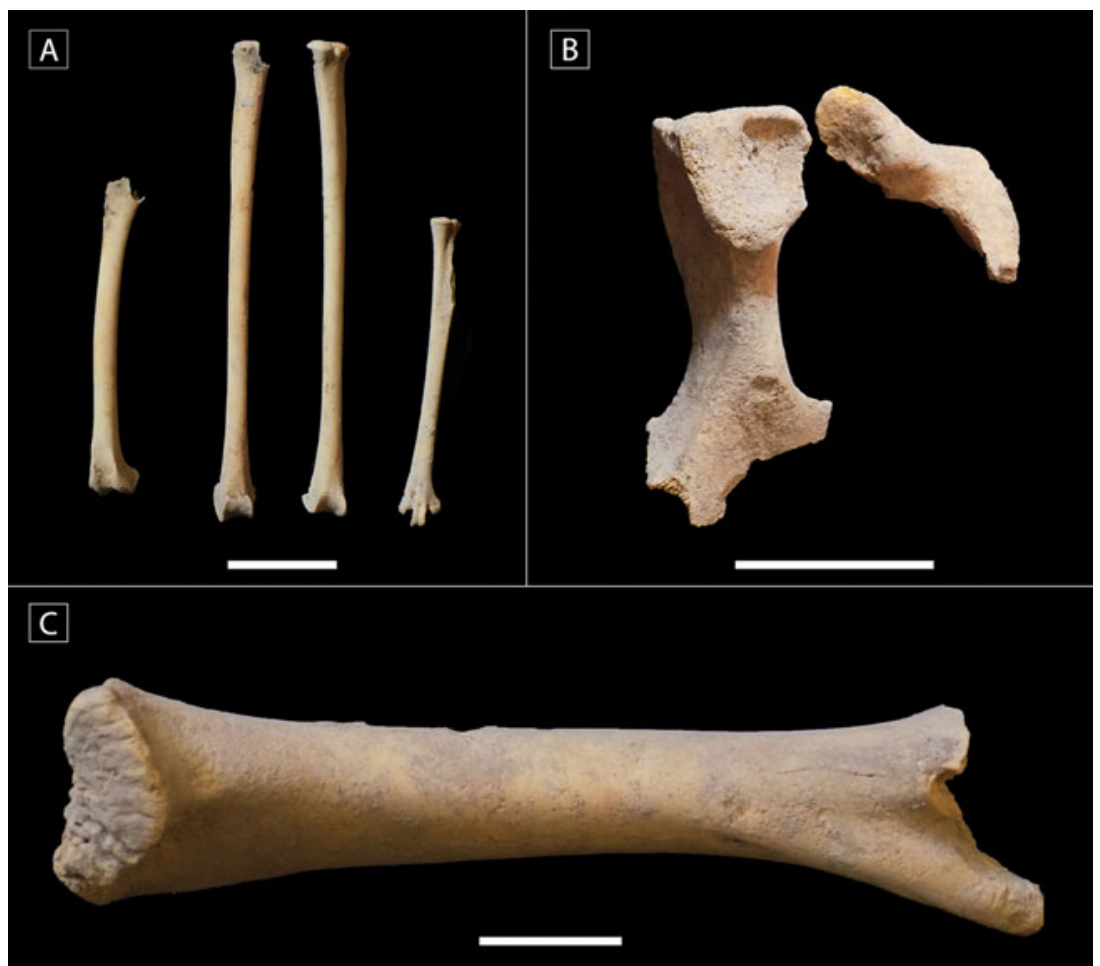

goddess 'ix.tzutz.sak' embodied these structures; this relationship perhaps also indicated an antiquity to the process of her becoming the sweat bath, one that was anchored in social memory and perhaps recounted as myth. The individual recovered within the doorway of Los Sapos may support this interpretation. Burning was observed on these human remains, but their fragmentary nature prevents a conclusive identification of the individual's sex, and also yields a wide age range of $12+$ years (Hannigan 2019). Perhaps alluding to her defeat, 'ix.tzutz.sak' is also depicted in a manner similar to defeated captives. As illustrated in the Yaxha examples discussed earlier, rulers perform period renewal rituals-actions tied to those of the hero twins that secured the conditions for human life-while standing on top of her head or within her mouth. Similar performed interactions are suggested by the Los Sapos architecture; one ascended the body of 'ix.tuztz.sak' in order to stand on top of her head or within her mouth. Although these connections remain loosely tied to later accounts of

Table 3. Evidence of burning within the assemblages. Percentages based on number of individual specimens within the context area, including unidentified vertebrates but excluding terrestrial snails. No evidence of burning was recovered from the EC/LC construction fill context.

\begin{tabular}{|l|l|c|c|c|}
\hline & Common name & $\begin{array}{c}\text { EC/LC } \\
\text { burial in } \\
\text { doorway } \\
\text { NISP }\end{array}$ & $\begin{array}{c}\text { LC/TC } \\
\text { large deposit within cist } \\
\text { construction } \\
\text { NISP }\end{array}$ & $\begin{array}{c}\text { LC/TC } \\
\text { deposit outside cist } \\
\text { construction } \\
\text { NISP }\end{array}$ \\
\hline Odocoileus virginianus & white-tailed deer & 0 & 0 & $1(1.1 \%)$ \\
\hline $\begin{array}{l}\text { Mammalia, medium/ } \\
\text { large size }\end{array}$ & $\begin{array}{l}\text { mammal, size of deer, human } \\
\text { or tapir }\end{array}$ & $1(1.9 \%)$ & $6(1.2 \%)$ & $1(1.1 \%)$ \\
\hline Mammalia & mammal, unidentified & $2(3.8 \%)$ & $3(0.6 \%)$ & 0 \\
\hline Iguanidae & unidentified vertebrates & $6(11.3 \%)$ & $1(0.2 \%)$ & 0 \\
\hline Total & iguana & 0 & $2(0.4 \%)$ & 0 \\
\hline
\end{tabular}



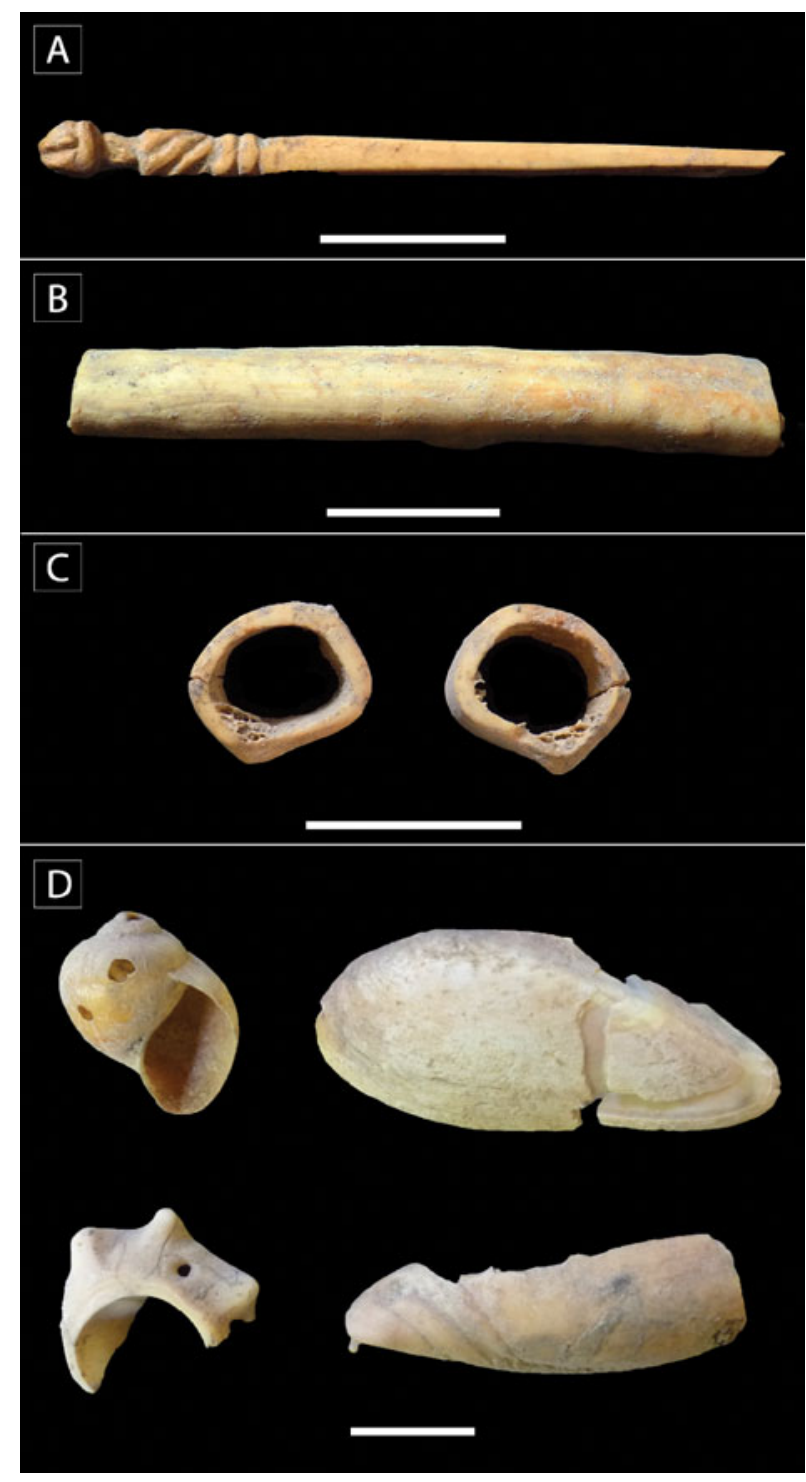

Figure 14. Examples of bone artifacts found in the deposit: (A) a finely crafted pin; (B) one of the bone tubes found in the deposit, this example having been carved across the exterior surface and not possible to identify to species; (C) two 'rings', probably cut from the same bone; (D) the four shells found together in the deposit: an apple snail (Pomacea flagellata), a freshwater mussel

(Unionidae), a fighting conch (Strombus pugilis) and an olive shell (Olividae). All scales $2 \mathrm{~cm}$.

Mesoamerican mythology, our evidence indicates that long after Los Sapos had been entombed, the Xultun population re-entered the cist tomb, removed most of an individual's burned remains and negotiated with the embodied entity. Their actions and offering suggest that, although buried, this personified sweat bath continued to have an active role in Xultun society well into the Terminal Classic period.
Xultun's permanent abandonment followed shortly after the deposit's assembly. Depopulation of the site had begun around $c$. AD 650-780, but the site's reservoirs, the primary sources of water, continued to be maintained until about cal. AD 980-1080, suggesting continued occupation. This gradual process of what is popularly referred to as the Maya 'collapse' can be seen across the Petén. As sites throughout this region were no longer engaging in monumental projects, Xultun inhabitants were still attempting to hold on to their Classic period reality. Not only did they commission and erect a new monumental stela, the last known in the Petén region; they also made this elaborate offering. By burning, breaking, suffocating and otherwise sacrificing the deposit's contents, they fed the supernatural being embodied in Los Sapos a considerable sum of vital life force or $k^{\prime} u h$. The inclusion of a juvenile human alongside other references to birth are particularly significant, as they reflect traits held in common among the goddesses embodied in Mesoamerican sweat baths. The identity and agency of the reptilian deity 'ix.tzutz.sak' was perhaps similarly understood. As the analogous examples suggest, this pernicious persona is 'consonant with the notion of the earth as a voracious mother who yields her fruits reluctantly and ultimately consumes her children' (Chinchilla Mazariegos 2017, 128). Given this identity and her perceived agency, an offering on this scale was most certainly an attempt at negotiation. Not yet ready to be the consumed children, Xultun inhabitants sought to pacify this being by offering her an exchange or offered substitution, akin to $k^{\prime} e x$ offerings discussed by Taube (1994). The conditions leading to this offering may have been understood as the supernatural entity attempting to expel them from the landscape possibly considered under her control. Rather than being a casual or convenient collection of both ritual and refuse items, the contents of the Los Sapos offering may, therefore, be an act of resilience, a strategy employed by a population seeking to maintain its hold on life at Xultun.

\section{Conclusions}

Although it is frequently difficult to determine the motive and history behind the placement of a ritual deposit in Maya archaeology, the circumstances of the Los Sapos sweat bath, with its unusually well preserved outer façade and intact offering within, allow a rare opportunity to assess such a practice. Careful excavation and stratigraphic dating retrace the history of the deposit, revealing that the final 
large offering took place centuries after the sweat bath had been ceremonially buried. The offering's content, including a human child, juvenile and aquatic animal remains and birth and parturition symbolism exhibited on the figurines, demonstrate associations with the sweat bath's later iconic role during the Postclassic and post-Contact periods as a place where women give birth. The cane toads and iguanas in the offering are a direct reference to the painted and sculpted stucco façades, indicating that those who made the deposit were familiar with what had been on the outside surface, even if they could no longer clearly see it during the Terminal Classic period. The Early Classic depiction of a crouching figure with limbs composed of iguana-toad conflations, perhaps the goddess 'ix. tzutz.sak', enveloped the structure, and may have been understood as both an embodied entity and the intended recipient of the final offering. Had the Los Sapos structure lacked its external façade, our ability to interpret the offering's contents would have been limited. Furthermore, if the contents of the offering had not been dated in association with the surrounding matrix, we may have misidentified this offering as a problematical or termination deposit made when the building was buried, rather than centuries later.

The similarities and differences among problematical deposits, we argue, suggest a common logic to ritual work among the Classic Maya. Although we cannot read the entire transcript of this discourse, it does not eliminate the reality that other layers of meaning (such as the significance of colour or texture, the representative nature of the items, be it social or geographic) were understood by those present during assembly. The distinctions we draw between the prescribed and specificrepurposed refuse in comparison to materials thematically related to place-do not aim to elevate one class of material above the other, but rather to evaluate how particular negotiations may be understood within the material assemblages that have, for the most part, been broadly classified. Because the function of the sweat bath Los Sapos is understood and its personified identity visually represented on its surfaces, we are able to illustrate the presence of an ontological relationship and question how this deposit reflects a material discourse between human and non-human populations. While it is not always possible to reconstruct such connections, our data suggest that the selection, treatment and assembly of problematical deposits were particular to circumstance and tailored to place.

\section{Acknowledgements}

This paper has profited immensely from discussions with many people over the years: Sarah Newman, David Carballo, Oswaldo Chinchilla Mazariegos, Alexandre Tokovinine, Julia Guernsey, Stephen Houston, David Stuart, Karl Taube, Bill Saturno, Franco Rossi, Elisa Mencos, David Del Cid, Edwin Román Ramírez, Jenny Wildt, Martin Rangle, Jane Rehl, Laura Health-Stout, Catherine Scott, Maria Codlin, Kathleen Forste. We would like to acknowledge the members of the Dolores, El Cruce, Santa Elena, Uaxactun, and other communities who shared their expertise and contributed to the recovery of this deposit. Finally, the paper has also profited from funding by Holden Williams, the Smithsonian Tropical Research Institute, National Geographic Society Expeditions Council Grant (\#EC0655-13), a David Scott Palmer award from Boston University's Center for Latin American Studies, and Boston University's Archaeology Program.

\section{Supplementary material}

Supplementary Tables 1 \& 2 may be found at https://doi.org/10.1017/S0959774320000281

Mary E. Clarke Archaeology Program Boston University 675 Commonwealth Ave Boston, MA 02215

USA

Email: meclarke@bu.edu

Ashley E. Sharpe Center for Tropical Paleoecology and Archaeology Smithsonian Tropical Research Institute Luis Clement Ave., Bldg. 401

Tupper Balboa Ancon Panama City Panama

Email: SharpeAE@si.edu

Elizabeth M. Hannigan Department of Anthropology California State University Chico

400 West First St Chico, CA 95929 USA

Email: ehannigan1@mail.csuchico.edu

Megan E. Carden HistoryMiami Museum University of Miami 
101 West Flagler St

Miami, FL 33130

USA

Email:Mec2301@columbia.edu

Gabriella Velásquez Luna

Department of Archaeology

Universidad de San Carlos de Guatemala

Building S-1, $2^{\text {nd }}$ Level

Zone 12, Guatemala City

Guatemala

Email:LunaArq14@gmail.com

Boris Beltrán

Department of Anthropology

Skidmore College

815 North Broadway

Saratoga Springs, NY 12866

USA

Email:bbeltran@skidmore.edu

Heather Hurst

Department of Anthropology

Skidmore College

815 North Broadway

Saratoga Springs, NY 12866

USA

Email: hhurst@skidmore.edu

\section{References}

Alberti, B. \& T.L. Bray, 2009. Animating archaeology: of subjects, objects and alternative ontologies. Cambridge Archaeological Journal 19(3), 337-43.

Alberti, B. \& Y. Marshall, 2009. Animating archaeology: local theories and conceptually open-ended methodologies. Cambridge Archaeological Journal 19(3), 34456.

Alcina Franch, J., 2000. Temazcalli: Higiene, Terapéutica, Obstetricia y Ritual en el Nuevo Mundo [Sweat bath: hygiene, therapeutics, obstetrics, and ritual in the New World]. Seville: Escuela de Estudios Hispano-Americanos, Consejo Superior de Investigaciones Científicas.

Ambrosino, J.N., 2003. The function of a Maya palace at Yaxuna: a contextual approach, in Maya Palaces and Elite Residences: An interdisciplinary approach, ed. J. J. Christie. Austin (TX): University of Texas Press, 253-73.

Arnal, W.E. \& R.T. McCutcheon, 2013. The Sacred is the Profane: The political nature of 'religion'. Oxford: Oxford University Press.

Balanzario, S., 2011. Primera parte: acumulaciones inusuales de materiales arqueológicos [Part one: Unusual accumulations of archaeological materials], in Kohunlich: Accumulaciones Inusuales y Figurillas [Kohunlich: Unusual accumulations and figurines], eds E. Nalda \& S. Balanzario. Mexico City: National Institute of Anthropology and History, 13-153.

Bartolomé, M.A., 1984. El Cielo Mítico de los Gemelos Sol y Luna en las Tradiciones de las Culturas Oaxaqueñas \{The mythic sky of the sun and moon twins within the traditions of Oaxacan Cultures]. Oaxaca: Instituto Nacional de Antropología e Historia, Centro Regional de Oaxaca.

Becker, M.J., 1993. Earth offering among the Classic period lowland Maya: burials and caches as ritual deposits, in Perspectivas Antropológicas en el Mundo Maya [Anthropological Perspectives of the Maya World], eds M.J. Iglesias Ponce de León \& F.d.A. Ligorred Perramón. Madrid: Sociedad Española de Estudios Mayas, 45-74.

Beliaev, D. \& A. Davletshin, 2014. 'It was then that that which had been clay turned into a man': reconstructing Maya anthropogenic myths. Axis Mundi: Journal of the Slovak Association for the Study of Religions 1, 2-12.

Bird-David, N., 1999. 'Animism' revisited: personhood, environment, and relational epistemology. (Special Issue: Culture-A Second Chance?) Current Anthropology 40(S1), 67-91.

Brown, L.A. \& K.F. Emery, 2008. Negotiations with the animate forest: hunting shrines in the Guatemalan highlands. Journal of Archaeological Method and Theory 15, 300-37.

Brown, M.K. \& J. F. Garber, 2003. Evidence of conflict during the Middle Preclassic in the Maya lowland: a view from Blackman Eddy, Belize, in Ancient Mesoamerican Warfare, eds M.K. Brown \& T. W. Stanton. Walnut Creek (CA): Altamira, 91-108.

Brück, J., 1999. Ritual and rationality: some problems of interpretation in European archaeology. European Journal of Archaeology 2(3), 313-44.

Carrasco Vargas, R., V.A. Vázquez López \& S. Martin, 2009. Daily life of the ancient Maya recorded on murals at Calakmul, Mexico. Proceedings of the National Academy of Sciences 106(46), 19245-9.

Carroll, R.L., 2015. War Trophies and Ancestor Veneration, A Bioarchaeological Analysis of Maya Secondary Interments at Formative Cuello and $\mathrm{K}^{\prime} \mathrm{axob}$ in Northern Belize. Master's thesis, University of Houston.

Chase, D.Z., 1994. Human osteology, pathology, and demography as represented in the burials of Caracol, Belize, in Studies in the Archaeology of Caracol, Belize, eds D.Z. Chase \& A.F. Chase. San Francisco (CA): Precolumbian Art Research Institute, 123-38.

Chase, D.Z. \& A.F. Chase, 1998. Architectural context of caches, burials, and other ritual activities, in Function and Meaning in Classic Maya Architecture, ed. S.D. Houston. Washington (DC): Dumbarton Oaks Research Library and Collections, 299-332.

Child, M.B., 2006. The Archaeology of Religious Movements: The Maya Sweatbath Cult of Piedras Negras. PhD dissertation, Yale University. 
Child, M.B. \& C.W. Golden, 2008. The transformation of abandoned architecture at Piedras Negras, in Ruins of the Past: The use and perception of abandoned structures in the Maya lowlands, eds T.W. Stanton \& A. Magnoni. Boulder (CO): University Press of Colorado, 65-89.

Chinchilla Mazariegos, O., 2017. Art and Myth of the Ancient Maya. New Haven (CT): Yale University Press.

Chinchilla Mazariegos, O., 2018. Fire and sacrifice in Mesoamerican myths and rituals, in Smoke, Flames, and the Human Body in Mesoamerican Ritual Practice, eds A.K. Scherer \& V. Tiesler. Washington (DC): Dumbarton Oaks Research Library and Collections, 29-53.

Chinchilla Mazariegos, O., V. Tiesler, O. Gómez \& T. D. Price, 2015. Myth ritual and human sacrifice in Early Classic Mesoamerica: interpreting a cremated double burial from Tikal, Guatemala. Cambridge Archaeological Journal 25(1), 187-210.

Christenson, A.J., 2003. Popol Vuh: The Sacred Book of the Maya. New York (NY): O Books.

Clarke, M.E., in press. Myth, ritual, and the ancient Maya sweat bath. RES: Anthropology and Aesthetics.

Clayton, S.C., W.D. Driver \& L.J. Kosakowsky, 2005. Rubbish or ritual? Contextualizing a Terminal Classic problematical deposit at Blue Creek, Belize: a response to 'Public architecture, ritual, and temporal dynamics at the Maya center of Blue Creek, Belize'. Ancient Mesoamerica, 16(1), 119-30.

Coe, W.R., 1959. Piedras Negras Archaeology: Artifacts, caches, and burials. Philadelphia (PA): University Museum, University of Pennsylvania.

Coe, W.R., 1965. Caches and offertory practices of the Maya lowlands, in Handbook of Middle American Indians, Volume 2, ed. R. Wauchope. Austin (TX): University of Texas Press, 462-8.

Domenici, D., 2014. Cueva del lazo: child sacrifice or special funerary treatment? Discussion of a Late Classic context from the Zoque region of western Chiapas (Mexico), in The Bioarchaeology of Space and Place: Ideology, power, and meaning in Maya mortuary contexts, ed. G.D. Wrobel. New York (NY): Springer, 39-75.

Duday, H., 2009. The Archaeology of the Dead: Lectures in archaeothanatology. Oxford: Oxbow.

Durkheim, E., 1915. The Elementary Forms of Religious Life. London: George Allen \& Unwin.

Earle, D.M., 1986. The metaphor of the day in Quiche: notes on the nature of everyday life, in Symbol and Meaning Beyond the Closed Community: Essays in Mesoamerican ideas, ed. G.H. Gossen. Albany (NY): Institute for Mesoamerican Studies, SUNY Albany, $155-72$.

Eliade, M., 1959. The Sacred and the Profane: The nature of religion. New York (NY): Houghton Mifflin Harcourt.

Finamore, D. \& S.D. Houston (eds), 2010. Fiery Pool: The Maya and the mythic sea. New Haven (CT): Yale University Press.
Freidel, D.A. \& L. Schele, 1989. Dead kings and living temples: dedication and termination rituals among the ancient Maya, in Word and Image in Maya Culture, eds L. Schele, W.F. Hanks \& D.S. Rice. Salt Lake City (UT): University of Utah Press, 233-43.

Galinier, J., 1990. La Mitad del Mundo: Cuerpo y Cosmos en los Rituales Otomíes [The middle of the world: body and cosmos in Otomí rituals]. Mexico City: Universidad Nacional Autónoma de México, Centro de Estudios Mexicanos y Centroamericanos, and Instituto Nacional Indigenista.

Galinier, J., 2004. The World Below: Body and cosmos in Otomí Indian ritual. Boulder (CO): University Press of Colorado.

Garrison, T. \& D. Stuart, 2004. Un análisis preliminar de las inscripciones que se relacionan con Xultun, Petén, Guatemala [A preliminary analysis of the inscriptions related to Xultun, Petén, Guatemala], in XVII Simposio de Investigaciones Arqueológicas ien Guatemala, 2003 [XVII Symposium of Archaeological Investigations in Guatemala, 2003], eds J.P. Laporte, B. Arroyo \& H. Mejía. Guatemala City: Instituto de Antropología e Historia de Guatemala, 851-62.

Girard, R., 1962. Los Mayas Eternos [The eternal Maya]. Mexico City: Antigua Libreria Robredo.

Gossen, G.H., 2002. Four Creations: An epic story of the Chiapas Mayas. Norman (OK): University of Oklahoma Press.

Graulich, M., 2005. Autosacrifice in ancient Mexico. Estudios de Cultura Náhuatl 36, 301-29.

Graulich, M. \& G. Olivier, 2004. ¿Deidades insaciables? La comida de los dioses en el México antiguo [Insatiable gods? The food of the gods of ancient Mexico]. Estudios de Cultura Náhuatl 25, 121-55.

Groleau, A.B., 2009. Special finds: locating animism in the archaeological record. Cambridge Archaeological Journal 19(3), 398-406.

Grube, N. \& W. Nahm, 1994. A census of Xibalba: a complete inventory of 'way' characters on Maya ceramics, in The Maya Vase Book: A corpus of rollout photographs of Maya vases, ed. J. Kerr. New York (NY): Kerr Associates, 686-715.

Guiteras Holmes, C., 1961. Perils of the Soul: The world view of a Tzotzil Indian. New York (NY): Free Press of Glencoe.

Haber, A.F., 2009. Animism, relatedness, life: post-western perspectives. Cambridge Archaeological Journal 19(3), 418-30.

Hallowell, A.I., 1960. Ojibwa Ontology, Behavior, and World View. New York (NY): Columbia University.

Hanks, W.F., 1990. Referential Practice: Language and lived space among the Maya. Chicago (IL): University of Chicago Press.

Hannigan, E., 2019. Estudio bioarqueológico: los entierros de la estructura XUL-12F5, Los Sapos [A bioarchaeological study: the burials from structure XUL-12F5, Los Sapos], in Proyecto Regional Arqueológico San Bartolo-Xultun: Resultados de Investigaciones, Año 2019 [San Bartolo-Xultun Regional Archaeological 
Project: investigation results from the 2019 season], eds H. Hurst \& B.F. Beltrán. Report submitted to Dirección General del Patrimonio Cultural y Natural de Guatemala, 103-22.

Harrison-Buck, E., 2015. Architecture as animate landscape: circular shrines in the ancient Maya lowlands. American Anthropologist 114(1), 64-80.

Harrison-Buck, E., 2018. Relational matters of being: personhood and agency in archaeology, in Relational Identities and Other-than-Human Agency in Archaeology, eds E. Harrison-Buck \& J. Hendon. Boulder (CO): University Press of Colorado, 263-82.

Harvey, G., 2006. Animals, animists, and academics. Zygon 41(1), 9-20.

Haviland, W., 2014. Excavations in Residential Areas of TikalNonelite Groups Without Shrines: Tikal Report $20 A$. Philadelphia (PA): University Museum, University of Pennsylvania.

Henare, A.J.M., M. Holbraad \& S. Wastell (eds), 2007. Thinking through Things: Theorising artefacts ethnographically. London: Routledge.

Hotaling, J., W. Saturno, B. Beltrán \& S. Suzuki, 2017. The Role of Offerings in Interpreting Maya Mortuary Ritual: Bioarchaeological Analysis at Xultun. Oral presentation at the 81st Annual Meeting of the Society for American Archaeology, Vancouver, British Columbia, 2017.

Houk, B.A., 2000. Life, the universe, and everything: re-evaluating problematic deposit 2 from Dos Hombres, Belize, in The 1998 and 1999 Seasons of the Chan Chich Archaeological Project, ed. B.A. Houk. Austin (TX): University of Texas Press, 141-50.

Houston, S.D., 1992. Classic Maya politics, in New theories on the Ancient Maya, eds E. Danien \& R. Sharer. Philadelphia (PA): University Museum of Archaeology and Anthropology, 65-70.

Houston, S.D., 1996. Symbolic sweatbaths of the Maya: architectural meaning in the cross group at Palenque, Mexico. Latin American Antiquity 7(2), 132-51.

Houston, S.D., 2014. The Life Within: Classic Maya and the Matter of Permanence. New Haven (CT): Yale University Press.

Houston, S.D., D. Stuart \& K. Taube, 2006. The Memory of Bones: Body, being, and experience among the Classic Maya. Austin (TX): University of Texas Press.

Ichon, A., 1973. La Religión de los Totonacas de la Sierra [The religion of the Totonacas of Sierra]. Mexico City: Dirección General de Publicaciones del Consejo Nacional para la Cultura y las Artes, Instituto Nacional Indigenista.

Iglesias Ponce de León, M.J., 1988. Análisis de un depósito problemático de Tikal, Guatemala [Analysis of a problematical deposit from Tikal]. Société des Américanistes 74, 25-48.

Ingold, T., 2006. Rethinking the animate, re-animating thought. Ethnos 71(1), 9-20.

Jones, O.A., 2018. Mycenaean secondary burial revisited: legacy data, taphonomy, and the process of burial in Achaia, Greece. Bioarchaeology International 2(4), 217-39.

Kieffer, C.L., 2015. Sacrifice of the social outcasts: two cases of Klippel-Feil syndrome at Midnight Terror Cave, Belize. International Journal of Osteoarchaeology 27(1), 45-55.

López Garcia, J., 2010. Kumix: La Lluvia en la Mitología y Ritual Maya-Ch'orti' [Kumix: rain within Ch'orti' Maya myth and ritual]. Guatemala City: Cholsamaj.

Mason, A.J., 1935. Mexican and Maya sweat-baths. Museum Bulletin 6(2), 65-9.

Massey, V.K. \& D.G. Steele, 1997. A Maya skull pit from the Terminal Classic period, Colha, Belize, in Bones of the Maya: Studies of ancient skeletons, eds S.L. Whittington \& D.M. Reed. Tuscaloosa (AL): University of Alabama Press, 62-77.

McAnany, P.A., 2010. Ancestral Maya Economies in Archaeological Perspective. Cambridge: Cambridge University Press.

Mock, S.B. (ed.), 1998. The Sowing and the Dawning: Termination, dedication, and transformation in the archaeological and ethnographic record of Mesoamerica. Albuquerque (NM): University of New Mexico Press.

Monaghan, J., 1995. The Covenants with Earth and Rain: Exchange, sacrifice, and revelation in Mixtec sociality. Norman (OK): University of Oklahoma Press.

Monaghan, J., 2000. Theology and history in the study of Mesoamerican religions, in Supplement to the Handbook of Middle American Indians, vol. 6, Ethnology, ed. J.D. Monaghan. Austin (TX): University of Texas Press, 24-49.

Moutafi, I. \& S. Voutsaki, 2016. Commingled burials and shifting notions of the self at the onset of the Mycenaean era (1700-1500 BCE): the case of the Ayios Vasilios north cemetery, Laconia. Journal of Archaeological Science: Reports 10, 780-90.

Navarro-Farr, O.C., 2009. Ritual, Process, and Continuity in the Late to Terminal Classic Transition: Investigations at Structure M13-1 in the Ancient Maya Site of El Perú-Waka', Petén, Guatemala. PhD dissertation, Southern Methodist University.

Newman, S.E., 2019. Rubbish, reuse, and ritual at the ancient Maya site of El Zotz, Guatemala. Journal of Archaeological Method and Theory 26, 806-43.

Nondédéo, P., A. Lacadena \& A. Garay, 2018. Apuntes epigráficos: la temporada 2015 del Proyecto Naachtun [Epigraphic notes: the Naachtun Project, 2015 season], in Tiempo Detenido, Tiempo Suficiente: Ensayos y Narraciones Mesoamericanistas en Homenaje a Alfonso Lacadena Garcia-Gallo [Stopped time, sufficient time: Mesoamericanist essays and stories in honour of Alfonso Lacadena Garcia-Gallo], eds H. Kettunen, V.A. Vázquez Lopez, F. Kupprat, C. Vidal Lorenzo, G. Munoz Cosme \& M.J. Iglesias Ponce de Leon. Couvin: European Association of Mayanists WAYEB, 329-50.

Novotny, A.C., 2017. Defining community in the upper Belize river valley during the Late Classic period: a 
microregional bioarchaeological approach. Archaeological Papers of the American Anthropological Association 28(1), 54-65.

Nuttall, Z. (ed.), 1903. The Book of the Life of the Ancient Mexicans, Containing an Account of Their Rites and Superstitions: An anonymous Hispano-Mexican manuscript preserved at the Biblioteca Nazionale Centrale, Florence, Italy, reproduced in facsimile, with introduction, translation, and commentary by Zelia Nuttall. Part I. Introduction and facsimile, Volume 1. Berkeley (CA): University of California.

Pendergast, D.M., 1998. Intercessions with the gods: caches and their significance at Altun $\mathrm{Ha}$ and Lamanai, Belize, in The Sowing and the Dawning: Termination, dedication, and transformation in the archaeological and ethnographic record of Mesoamerica, ed. S.B. Mock. Albuquerque (NM): University of New Mexico Press, 55-63.

Prufer, K.M. \& A. Kindon, 2005. Replicating the sacred landscape: the Chen at Muklebal Tzul, in Stone Houses and Earth Lords: Maya religion in the cave context, eds K.M. Prufer \& J.E. Brady. Boulder (CO): University Press of Colorado, 25-46.

Pugh, T.W., 2005. Caves and artificial caves in Late Postclassic Maya ceremonial groups, in Stone Houses and Earth Lords: Maya religion in the cave context, eds K.M. Prufer \& J.E. Brady. Boulder (CO): University Press of Colorado, 47-69.

Sahagún, B. de, 1950-1982. The Florentine Codex: General History of the Things of New Spain (trans. A.J.O. Anderson \& C.E. Dibble). (13 vols) Salt Lake City (UT): University of Utah Press.

Satterthwaite, L., 1952. Piedras Negras Archaeology: Architecture; Pt. V. Sweathouses. Philadelphia (PA): University Museum.

Schaefer, M., S. Black \& L. Scheuer, 2009. Juvenile Osteology. London: Academic Press.

Scherer, A.K., 2015. Mortuary Landscapes of the Classic Maya: Rituals of body and soul. Austin (TX): University of Texas Press.

Scherer, A.K., 2018. Grave matters: bioarchaeology and mortuary archaeology at El Zotz, Bejucal, and El Palmar, in An Inconstant Landscape: The Maya kingdom of El Zotz, Guatemala, eds T.G. Garrison \& S. D. Houston. Louisville (CO): University Press of Colorado, 303-60.

Scheuer, L. \& Black, S., 2000. Developmental Juvenile Osteology. San Diego (CA): Academic Press.

Shaw, M. (ed.), 1971. According to Our Ancestors: Folk texts from Guatemala and Honduras. Norman (OK): Summer Institute of Linguistics of the University of Oklahoma.

Smith, A.L., 1950. Uaxactun, Guatemala: Excavations of 19311937. Washington (DC): Carnegie Institute of Washington.

Stanton, T.W., M.K. Brown \& J.B. Pagliaro, 2008. Garbage of the gods? Squatters, refuse disposal, and termination rituals among the ancient Maya. Latin American Antiquity 19(3), 227-47.
Stuart, D., 2005. The Inscriptions from Temple XIX at Palenque: A Commentary. San Francisco (CA): Pre-Columbian Art Research Institute.

Taube, K.A., 1994. The birth vase: natal imagery in ancient Maya myth and ritual, in The Maya Vase Book: A corpus of rollout photographs of Maya vases, eds B. Kerr \& J. Kerr. New York (NY): Kerr Associates, 650-85.

Taube, K.A., 2004. Flower mountain: concepts of life, beauty, and paradise among the Classic Maya. RES: Anthropology and Aesthetics 45, 69-98.

Tedlock, D. (ed.), 1996. Popol Vuh: The Mayan Book of the Dawn of Life. New York (NY): Touchstone.

Thompson, E.J., 1963. Maya Archaeologist. Norman (OK): University of Oklahoma Press.

Tiesler, V., 2007. Funerary or nonfunerary? New references in identifying ancient Maya sacrificial and postsacrifical behaviors from human assemblages, in New Perspectives on Human Sacrifice and Ritual Body Treatments in Ancient Maya Society, eds V. Tiesler \& A. Cucina. New York (NY): Springer, 14-44.

Tiesler, V., O. Chinchilla Mazariegos, J. Chi, S. Chay \& O. Gómez, 2012. Fuego y sacrificio durante el Clásico Temprano: los restos humanos del entierro PP7TT-01 [Fire and sacrifice during the Early Classic period: the human remains from Tikal burial PP7TT-01], in XXVI Simposio de Investigaciones Arqueológicas en Guatemala [XXVI Symposium of Archaeological Investigations in Guatemala], eds B. Arroyo \& L. Méndez Salinas. Guatemala City: National Museum of Archaeology and Ethnology, 445-56.

Tiesler, V. \& A. Cucina, 2006. Procedures in human heart extraction and ritual meaning: a taphonomic assessment of anthropogenic marks in Classic Maya skeletons. Latin American Antiquity 17(4), 493-510.

Tiesler, V., A. Cucina \& A. Romano Pacheco, 2002. Vida y muerte del personaje hallado en el Templo XIII-sub, Palenque: 1 Culto funerario y sacrificio humano [Life and death of the individual recovered in Temple XIII-sub, Palenque: 1 Funerary cult and human sacrifice]. Mexicon 24, 75-8.

Tokovinine, A., 2013. Place and Identity in Classic Maya Narratives. (Studies in Pre-Columbian Art and Archaeology 37.) Washington (DC): Dumbarton Oaks Research Library and Collections.

Tozzer, A.M. (ed. \& trans.), 1941. Landa's Relación de los Cosas de Yucatán: A translation. (Papers of the Peabody Museum of Archaeology and Ethnology 18.) Cambridge (MA): Harvard University.

Tylor, E.B., [1871] 1993. Primitive Culture: Researches into the development of mythology, philosophy, religion, art, and custom. London: J. Murray.

Urquizú, M. \& H.V. Pérez, 2019. Xultun: secuencia cerámica [Xultun: ceramic sequence], in Proyecto Regional Arqueológico San Bartolo-Xultun: Resultados de Investigaciones, Año 2019 [San Bartolo-Xultun Regional Archaeological Project: results of investigations, 2019], eds H. Hurst \& B.F. Beltrán. Report 
submitted to Dirección General del Patrimonio Cultural y Natural de Guatemala, 123-94.

Vogt, E.Z., 1969. Zinacantan: A Maya community in the highlands of Chiapas. Cambridge (MA): Harvard University Press.

Vogt, E.Z. \& D. Stuart, 2005. Some notes on ritual caves among the ancient and modern Maya, in In the Maw of the Earth Monster: Mesoamerican ritual cave use, eds J.E. Brady \& K.M. Prufer. Austin (TX): University of Texas Press, 155-85.

Wagley, R., 1949. The Social and Religious Life of $A$ Guatemalan Village. (Memoir 71.) Menasha (WI): American Anthropological Association.

Wildt, J.C.G., 2015. A Tale of Three Plazas: The Development and Use of Public Spaces in a Classic Maya Ritual and Ceremonial Complex at Xultun, Guatemala. PhD dissertation, Boston University.

Wisdom, C., 1940. The Chorti Indians of Guatemala. Chicago (IL): University of Chicago Press.

Wrobel, G.D., R. Shelton, S. Morton, J. Lynch \& C. Andres, 2013. The view of Maya cave ritual from the Overlook rockshelter, Caves Branch river valley, Central Belize. Journal of Cave and Karst Studies 75(2), 126-35.

Źrałka, J., W. Koszkul, B. Hermes, J.L. Velásquez, V. Matute \& B. Pilarski, 2017. From e-group to funerary pyramid: mortuary cults and ancestor veneration in the Maya centre of Nakum, Petén, Guatemala. Cambridge Archaeological Journal 27(3), 451-78.

\section{Author biographies}

Mary E. Clarke is a Lecturer in the Archaeology Program at Boston University. Her research is multidisciplinary-integrating material studies, iconography and archaeologyand considers the diverse ways Mesoamerican people have negotiated with and modified their landscape. Currently, her research addresses the intersection of limestone quarries and Classic Maya economies through the lens of producer households and quarry workshops in order to evaluate the socio-economic dimension of monumental art and architecture.

Ashley E. Sharpe is a zooarchaeologist at the Smithsonian Tropical Research Institute in Panama. Her research examines how humans have interacted with the environment, particularly animals, in Central America over time. She is particularly interested in the diverse ways that humans have adapted to the landscape to sustain communities of variable size, including how they hunted and sometimes even managed wild and domestic species, and also how their perception of different animals is reflected in their social activities and art.
Elizabeth M. Hannigan is a master's student at California State University, Chico, in the Department of Anthropology. She received her bachelor's degree in archaeology from Boston University where her honours thesis features an osteobiography of a Classic Maya female from Xultun, Guatemala. Her current research centres on forensic anthropology and its applications for improving the identification of unidentified decedents from marginalized communities.

Megan E. Carden is a museum education and collections professional at HistoryMiami Museum and a research volunteer in the University of Miami Archaeological Stable Isotope Laboratory. She earned her Bachelor of Arts degree in anthropology from Brandeis University and plans to pursue her master's degree in museum anthropology at Columbia University. She is particularly interested in the use of archaeological research and collections in museum exhibitions, education and outreach.

Gabriela Velásquez Luna earned her Licenciatura degree in archaeology from Universidad de San Carlos, Guatemala, where she also earned her master's degree in restoration from the Faculty of Architecture, specializing in heritage monuments. She is currently directing a research programme at the Consejo Nacional para la Protección de la Antigua, Guatemala, that is focused on the excavation and restoration of sixteenth- and early twentieth-century architecture.

Boris Beltrán is an archaeologist specializing in ancient Maya and pre-Columbian archeology of Guatemala and Honduras. He has conducted fieldwork at various sites throughout Mesoamerica, including El Motagua Medio, El Zotz, El Tintal and Río Amarillo, among others. As co-director of the San Bartolo-Xultún Regional Archaeological Project, his research and academic contributions have been focused on early writing systems, the evolution of ceremonial architecture and the socio-political relationships of the cities within the project area during the Early Preclassic and Classic periods.

Heather Hurst is an archaeologist and archaeological illustrator who received her $\mathrm{PhD}$ in anthropology from Yale University, completing a multi-site investigation of wall paintings in the Maya lowlands. She has participated in 20 years of fieldwork in Mesoamerica, including the sites of Bonampak, Copán, Holmul, Oxtotitlán, Palenque and Piedras Negras, with research interests including artists' materials and practice, architecture, conservation and cultural heritage preservation. Hurst is director of the Proyecto Regional Arqueológico San Bartolo-Xultun, Guatemala. 